Federal Reserve Bank of Dallas

Globalization and Monetary Policy Institute

Working Paper No. 80

http://www.dallasfed.org/assets/documents/institute/wpapers/2011/0080.pdf

\title{
Monetary Policy, Capital Inflows, and the Housing Boom*
}

\author{
Filipa Sá \\ Trinity College \\ University of Cambridge \\ Tomasz Wieladek \\ London Business School
}

April 2011

\begin{abstract}
We estimate an open economy VAR model to quantify the effect of monetary policy and capital inflows shocks on the US housing market. The shocks are identified with sign restrictions derived from a standard DSGE model. We find that monetary policy shocks have a limited effect on house prices and residential investment. In contrast, capital inflows shocks driven by an increase in foreign savings have a positive and persistent effect on both housing variables. Other sources of capital inflows shocks, such as foreign monetary expansion or an increase in aggregate demand in the US, have a more limited role.
\end{abstract}

JEL codes: E5, F3

\footnotetext{
* Filipa Sá, Trinity College, University of Cambridge, Trinity Street, CB2 1 TQ, United Kingdom. +44-(0)20-7601-5940. Fgs22@cam.ac.uk. Tomasz Wieladek, London Business School. tomasz.wieladek@bankofengland.co.uk. The authors wish to thank Andrea Ferrero for sharing his codes and Martin Brooke, Phil Evans, Linda Goldberg, Glenn Hoggarth, Nobuhiro Kiyotaki, Gary Koop, Haroon Mumtaz, Adrian Pagan, Ugo Panizza, Matthias Paustian, Hashem Pesaran and Cédric Tille for helpful suggestions. Andreas Baumann and Richard Edghill provided excellent assistance with the data. The views in this paper are those of the authors and do not necessarily reflect the views of the Federal Reserve Bank of Dallas or the Federal Reserve System.
} 


\section{Introduction}

One of the major sources of the financial and economic problems of the last three years was the collapse of the housing boom that had been developing in the United States since the mid-1990s. This paper considers the relative importance of two potential causes of the boom:

1. Global imbalances. One view is that the housing boom was caused by the increase in capital inflows to the US that has been occurring since the mid-1990s. During that period, the US current account deficit widened while other countries, especially oil exporters and Asian economies, have been building surpluses. The flow of capital from EMEs to the US generated an increase in liquidity in the US financial system and drove down long term real interest rates. Low interest rates reduced the cost of borrowing and encouraged a credit boom and an increase in house prices. Low risk-free rates led portfolio investors to allocate a larger part of their wealth to higher yielding (and riskier) assets, including US sub-prime residential mortgage backed securities and leveraged corporate loans. This hypothesis is advanced in King (2009) who suggests that "the origins of the crisis lie in the imbalances in the world economy which built up over a decade or more".

2. Loose monetary policy in the US. This explanation also stresses the role of low interest rates in generating the housing boom. However, it attributes the decrease in interest rates to monetary policy loosening rather than an increase in foreign capital inflows. According to this explanation, a fear of deflation led the Federal Reserve to keep short term interest rates too low for too long. The reduction in the cost of borrowing encouraged a credit boom and an increase in house prices. This is the view in Taylor (2009), who shows that, since the early 2000s, the Federal Funds rate has been significantly lower than the level implied by the Taylor rule.

Both explanations could have some merit. How much weight should we put on each one?

Figure 1 shows the evolution of the US current account balance and house prices. It is clear that the build up in house prices since the mid-1990s happened at the same time as the widening in the US current account deficit. However, this does not imply causality and does not rule out the possibility of both variables being driven by some third factor. 
Figure 1. Current account balance and house prices

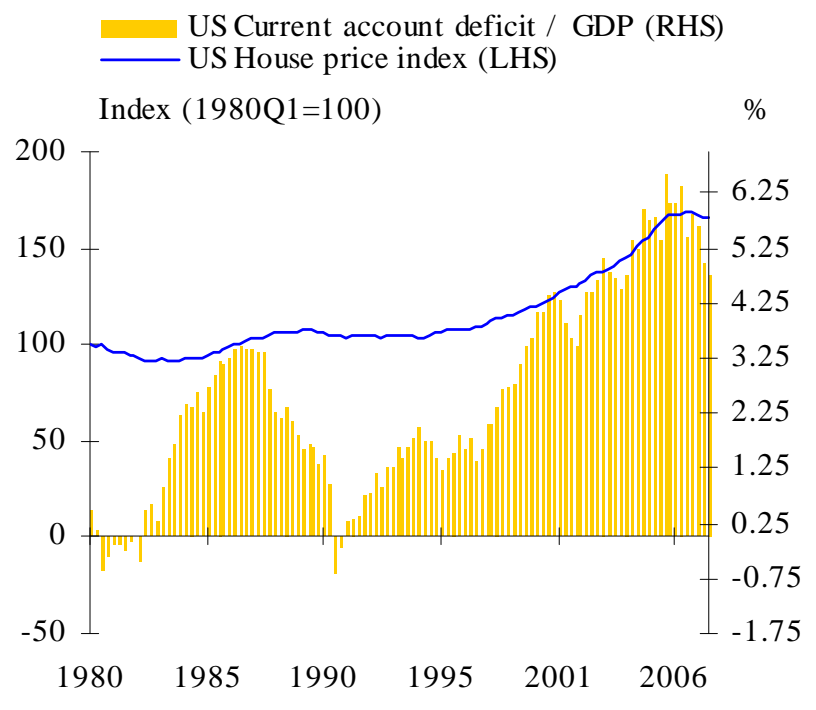

Figure 2. US short term and long term nominal interest rates

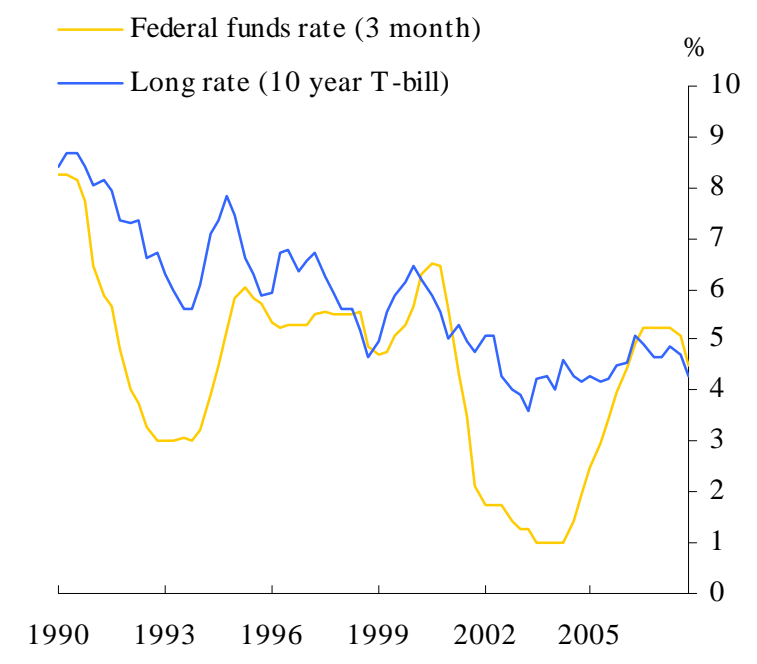

Sources: OECD Economic Outlook, Federal Housing Finance Agency (FHFA). Source: IMF IFS and Federal Reserve Economic Data (FRED).

A piece of suggestive evidence in support of the hypothesis that global imbalances played a central role in the housing boom is the evolution of short and long-term nominal interest rates in the US (Figure 2). As has been well documented, despite the rise in short-term interest rates from 2004 until the current crisis, long-term bond yields have remained low - the so-called 'long rate conundrum' (Greenspan (2005)). This can be seen as evidence in favour of the global imbalances story: even though the Fed was increasing policy rates, long rates remained low over a period in which the US current account deficit kept rising. However, there are other factors which may explain the low level of long rates, for example high corporate savings or an increase in monetary policy credibility. And the increase in short rates from 2004 to 2007 does not immediately discard the loose monetary policy story. This story is not simply about changes in short rates, but rather about deviations from the appropriate level of rates as suggested, for example, by the Taylor rule. Figure 3 shows that, even though the Fed has been increasing rates in the period from 2004 to 2007 , rates were still kept at a level lower than what would be implied by the Taylor rule. 
Figure 3. Actual and counterfactual (Taylor rule) Federal funds rate

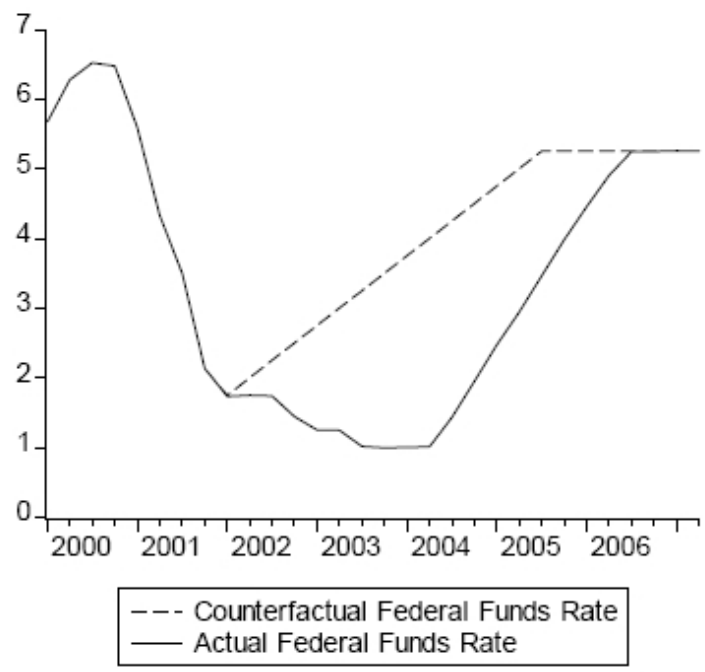

Source: Taylor (2009).

A simple look at the data does not allow us to assess which of the two explanations is correct. At present there are not yet many studies trying to disentangle its causes and quantify the relative contribution of different factors. In a recent speech, Bernanke (2010) discusses the link between monetary policy and house prices in the run up to the crisis. Using cross-country evidence, he shows that "countries in which current accounts worsened and capital inflows rose had greater house price appreciation" in the period from 2001Q4 to 2006Q3. He concludes that capital inflows seem to be a promising avenue for explaining cross-country differences in real house price growth.

Capital inflows into the US could be driven by different factors. For example, they could result from an increase in savings abroad, which pushes down long-term world interest rates and leads to an inflow of capital into the US, a deterioration of the US current account and an appreciation of the dollar - this is the 'savings glut' hypothesis suggested in Bernanke (2005). Alternatively, a monetary policy expansion abroad would reduce foreign interest rates and increase the relative attractiveness of US assets, leading to capital inflows into the US. These two hypotheses — 'savings glut' and monetary expansion abroad - point to external factors as explanations for the US current account deficit. An alterative view attributes the deficit to domestic factors, in particular an increase in domestic aggregate demand and a reduction in domestic savings. It is also possible that the reduction in macroeconomic volatility experienced in the US since the mid-1980s - the socalled "great moderation" - reduced precautionary savings in the US and increased the perceived safety of US assets, attracting capital flows from abroad. We develop a framework to identify the contribution of US monetary policy and of these different sources of capital inflows to the housing boom.

There is a relatively large literature on the effect of monetary policy on house prices. Iacoviello (2005) estimates a VAR on interest rates, inflation, detrended output and house prices using US data from 1974 to 2003. He identifies monetary policy shocks through a Choleski decomposition and finds that monetary policy shocks have a significant effect on house prices. Del Negro and Otrok 
(2007) estimate a VAR on the Federal Funds rate, the mortgage rate, total reserves of depository institutions, GDP, the GDP deflator, and the common factor of state-level house prices in the US. They adopt a different identification strategy from Iacoviello and use sign restrictions on the impulse responses to identify monetary policy shocks. The house price factor shows a significant and persistent drop following a contractionary monetary policy shock. However, in a counterfactual exercise, Del Negro and Otrok simulate the evolution of the house price factor in the absence of monetary policy shocks and find a small difference between the actual and the simulated series. This suggests that the impact of monetary policy shocks on house prices is small in comparison with the magnitude of recent fluctuations. Jarociński and Smets (2008) estimate a nine-variable VAR for the US and identify monetary policy shocks using a combination of zero and sign restrictions. They find that a monetary policy shock which reduces the Federal Funds rate by 25 basis points generates an immediate reduction in real house prices. The reduction reaches its peak of about $0.5 \%$ two and a half years after the shock.

There are also some studies looking at the effect of capital flows on US interest rates. Warnock and Warnock (2009) estimate that, if there had been no foreign official flows into US government bonds over the course of a year, long rates would be almost 100 basis points higher. Focusing on the spread between the yields on long maturity corporate bonds and Treasury bonds, Krishnamurthy and Vissing-Jorgensen (2007) find that, if governmental holders (foreign central banks, US Federal Reserve banks, state and local governments) were to sell their holdings of US Treasuries and exit the market, the yield on US Treasuries would rise by the same amount as the yield on corporate bonds. Caballero and Krishnamurthy (2009) develop a model to show how capital flows to the US triggered a sharp rise in asset prices and a decrease in risk premia and interest rates. All these studies point to a link between low US long interest rates and the demand for US assets by foreign savers.

The study that is closest to ours is Bracke and Fidora (2008) which explains the evolution of the US current account balance and asset prices by three types of shocks: monetary policy shocks, preference shocks (capturing changes in the savings rate), and investment shocks. The authors estimate two separate structural VARs, for the US and emerging Asia. For the US they look at a monetary policy expansion, a reduction in the savings rate and an increase in investment. For emerging Asia they define these shocks with the opposite signs (monetary policy contraction, increase in the savings rate and reduction in investment). The shocks are identified by imposing sign restrictions on the impulse responses. The findings suggest that monetary shocks explain the largest part of the variation in the US current account balance and asset prices.

Our paper develops an empirical framework to identify the relative contributions of US monetary policy and capital inflows to the housing boom. We estimate an open economy vector autoregressive (VAR) model with US and foreign variables and identify the effect of a US monetary policy expansion and of various shocks that increase capital flows to the US. Unlike Bracke and Fidora, we include both US and foreign variables in the VAR, allowing identification of home and foreign shocks simultaneously. Identification is achieved by imposing sign restrictions on the impulse responses, as 
in Uhlig (2005). The identifying sign restrictions are derived from a standard two-country dynamic stochastic general equilibrium (DSGE) model. To capture developments in the housing market, we look at the effect of different shocks on real residential investment and real house prices.

Consistent with the evidence in Bernanke (2010), our results suggest that shocks that reduce aggregate demand in the rest of the world - i.e., the 'savings glut' — have a significant and positive effect on real residential investment and real house prices, while monetary policy shocks have a smaller and less significant effect. One way of comparing the effects of different types of shocks is by computing the fraction of the variation in real residential investment and real house prices explained by each type of shock. We find that, at a forecast horizon of 20 quarters, negative aggregate demand shocks in the rest of the world explain about $7.5 \%$ of the variation in real residential investment and $10.7 \%$ of the variation in real house prices. By contrast, US monetary policy shocks explain less than $3 \%$ of the variation in both housing variables. Other shocks which generate capital inflows to the US explain a larger fraction of the variation in the housing variables than US monetary policy shocks, but are less important than 'savings glut' shocks.

The paper is structured as follows. Section 2 describes a standard DSGE model from which we derive the sign restrictions used to identify the structural VAR. Section 3 describes the econometric framework. Section 4 discusses the baseline empirical results and presents robustness checks. Section 5 concludes.

\section{Identification}

This section presents a standard DSGE model from which the sign restrictions used in the empirical exercise are derived. We follow closely the model in Ferrero, Gertler and Svensson (2007).

There are two countries: the US and the rest of the world (ROW). Each country has one representative household that consumes tradable and nontradable goods. Tradable goods can be produced at home or abroad. For simplicity, there are no capital goods.

In order to study current account dynamics, we assume imperfect international capital markets. In particular, there is a single bond that is traded internationally and is denominated in units of home currency. In addition, investors in ROW may hold a bond denominated in units of foreign currency which is not traded internationally.

\subsection{Model}

\subsubsection{Households}

The household has a continuum of workers who consume and supply labor in the intermediate goods sector. We assume that each worker works in a particular intermediate goods firm. Intermediate goods firms are denoted by $f \in[0,1]$, where $f \in[0, \gamma)$ produce tradable goods and $f \in(\gamma, 1]$ produce nontradable goods. 
The preferences of the household are given by:

$$
U_{t} \equiv E_{t} \sum_{s=0}^{\infty} \theta_{t+s-1} u_{t+s}
$$

where period utility $u_{t}$ is given by:

$$
u_{t} \equiv \log C_{t}-\left[\int_{0}^{\gamma} \frac{L_{H t}(f)^{1+\varphi}}{1+\varphi} d f+\int_{\gamma}^{1} \frac{L_{N t}(f)^{1+\varphi}}{1+\varphi} d f\right]
$$

$C_{t}$ is a composite of tradable $\left(C_{T t}\right)$ and nontradable $\left(C_{N t}\right)$ consumption goods:

$$
C_{t} \equiv \frac{C_{T t}^{\gamma} C_{N t}^{1-\gamma}}{\gamma(1-\gamma)}
$$

The Cobb-Douglas specification is employed to maintain analytical tractability. It implies an elasticity of substitution of unity between tradables and nontradables. In the calibration we let this elasticity (denoted by $\mu$ ) vary between 0.5 and 1.5 .

Tradable consumption goods are a composite of home $\left(C_{H t}\right)$ and foreign $\left(C_{F t}\right)$ tradables:

$$
C_{T t} \equiv\left[\alpha^{\frac{1}{\eta}} C_{H t}^{\frac{\eta-1}{\eta}}+(1-\alpha)^{\frac{1}{\eta}} C_{F t}^{\frac{\eta-1}{\eta}}\right]^{\frac{\eta}{\eta-1}}
$$

$L_{H t}(f)$ denotes hours worked by worker $f$ in the home tradable sector and $L_{N t}(f)$ denotes hours worked by worker $f$ in the nontradable sector.

To ensure a determinate steady state in the presence of incomplete international financial markets, the discount factor $\theta_{t}$ is endogenous and is determined by the recursion:

$$
\theta_{t}=\beta_{t} \theta_{t-1}
$$

with $\beta_{t} \equiv \frac{e^{\varsigma t}}{1+\varphi\left(\log \overline{C_{t}}-\vartheta\right)}$ where $\overline{C_{t}}$ is detrended consumption and $\varsigma_{t}$ is a preference shock, which follows a first order stochastic process:

$$
\varsigma_{t}=\rho_{\varsigma} \varsigma_{t-1}+u_{\varsigma t}, \quad u_{\varsigma t} \sim i . i . d . N\left(0, \sigma_{\varsigma}^{2}\right)
$$

A positive shock to $\varsigma_{t}$ increases the discount factor, making households more patient.

The household's budget constraint is give by:

$$
P_{t} C_{t}+B_{t}=I_{t-1} B_{t-1}+\int_{0}^{\gamma} W_{H t}(f) L_{H t}(f) d f+\int_{\gamma}^{1} W_{N t}(f) L_{N t}(f) d f+\tau_{t}
$$

where $B_{t}$ is nominal holdings at the beginning of period $t+1$ of an internationally traded oneperiod risk-free bond denominated in home currency, $I_{t}$ is the gross nominal domestic currency interest rate, $W_{t}(f)$ is the nominal wage of worker $f$ and $\tau_{t}$ are dividends net of lump sum taxes. The price index $P_{t}$ can be derived from the household's expenditure minimization problem given the 
consumption composites (1) and (2). It is given by the following function of the price of tradables $P_{T t}$ and the price of nontradables $P_{N t}$ :

$$
P_{t}=P_{T t}^{\gamma} P_{N t}^{1-\gamma}
$$

where the price of tradables $P_{T t}$ is a function of the price of home tradables $\left(P_{H t}\right)$ and the price of foreign tradables expressed in home currency $\left(P_{F t}\right)$ :

$$
P_{T t} \equiv\left[\alpha P_{H t}^{1-\eta}+(1-\alpha) P_{F t}^{1-\eta}\right]^{\frac{1}{1-\eta}}
$$

The law of one price holds for tradables, i.e.:

$$
\begin{aligned}
P_{H t} & =\frac{1}{\varepsilon_{t}} P_{H t}^{*} \\
P_{F t} & =\frac{1}{\varepsilon_{t}} P_{F t}^{*}
\end{aligned}
$$

where $\varepsilon_{t}$ is the nominal exchange rate defined such that an increase represents an appreciation of the home currency. Foreign currency prices are denoted with a star.

Households maximize utility subject to the budget constraint. This gives the standard Euler equation for consumption-savings decisions:

$$
E_{t}\left\{\beta_{t} I_{t} \frac{P_{t}}{P_{t+1}}\left(\frac{C_{t+1}}{C_{t}}\right)^{-1}\right\}=1
$$

and the labour supplies for each sector:

$$
\begin{aligned}
& \frac{W_{H t}(f)}{P_{t}} \frac{1}{C_{t}}=L_{H t}(f)^{\varphi} \\
& \frac{W_{N t}(f)}{P_{t}} \frac{1}{C_{t}}=L_{N t}(f)^{\varphi}
\end{aligned}
$$

The allocation of consumption between tradables and nontradables is given by:

$$
\begin{aligned}
C_{T t} & =\gamma\left(\frac{P_{T t}}{P_{t}}\right)^{-1} C_{t} \\
C_{N t} & =(1-\gamma)\left(\frac{P_{N t}}{P_{t}}\right)^{-1} C_{t}
\end{aligned}
$$

And the allocation between home and foreign tradables is given by: 


$$
\begin{aligned}
C_{H t} & =\alpha\left(\frac{P_{H t}}{P_{T t}}\right)^{-1} C_{T t} \\
C_{F t} & =(1-\alpha)\left(\frac{P_{F t}}{P_{T t}}\right)^{-1} C_{T t}
\end{aligned}
$$

\subsubsection{Firms}

Final Goods Sector Firms in the final goods sector combine intermediate goods to produce output using a CES production function:

$$
\begin{aligned}
Y_{H t} & \equiv\left[\gamma^{-\frac{1}{\sigma}} \int_{0}^{\gamma} Y_{H t}(f)^{\frac{\sigma-1}{\sigma}} d f\right]^{\frac{\sigma}{\sigma-1}} \\
Y_{N t} & \equiv\left[(1-\gamma)^{-\frac{1}{\sigma}} \int_{\gamma}^{1} Y_{N t}(f)^{\frac{\sigma-1}{\sigma}} d f\right]^{\frac{\sigma}{\sigma-1}}
\end{aligned}
$$

The elasticity of substitution between intermediate goods is given by $\sigma>1$.

From cost minimization we get the demands for intermediate goods:

$$
\begin{aligned}
& Y_{H t}(f)=\gamma^{-1}\left[\frac{P_{H t}(f)}{P_{H t}}\right]^{-\sigma} Y_{H t} \\
& Y_{N t}(f)=\gamma^{-1}\left[\frac{P_{N t}(f)}{P_{N t}}\right]^{-\sigma} Y_{N t}
\end{aligned}
$$

The price indices are aggregations of the prices of intermediate goods:

$$
\begin{aligned}
P_{H t} & =\left[\gamma^{-1} \int_{0}^{\gamma} P_{H t}(f)^{1-\sigma} d f\right]^{\frac{1}{1-\sigma}} \\
P_{N t} & =\left[(1-\gamma)^{-1} \int_{\gamma}^{1} P_{N t}(f)^{1-\sigma} d f\right]^{\frac{1}{1-\sigma}}
\end{aligned}
$$

Intermediate Goods Sector Firms in the intermediate goods sector produce output using only labor according to a linear production function:

$$
\begin{aligned}
& Y_{H t}(f)=A_{t} L_{H t}(f) \\
& Y_{N t}(f)=A_{t} L_{N t}(f)
\end{aligned}
$$

where $A_{t}$ is labor productivity.

Firms act competitively to minimize costs and set the nominal marginal cost equal to the nominal wage adjusted for productivity: 


$$
\begin{aligned}
M C_{H t}(f) & =\frac{W_{H t}(f)}{A_{t}} \\
M C_{N t}(f) & =\frac{W_{N t}(f)}{A_{t}}
\end{aligned}
$$

To introduce a role for monetary policy, the model includes nominal price rigidities. In particular, each period a fraction $\xi$ of intermediate goods firms do not adjust prices. The fraction $1-\xi$ that change prices set them to maximize the present discounted value of profits:

$$
\begin{aligned}
& E_{t} \sum_{s=0}^{\infty} \xi^{s} \Lambda_{t, t+s}\left[P_{H t}(f)-M C_{H, t+s}(f)\right] Y_{H, t+s}(f) \\
& E_{t} \sum_{s=0}^{\infty} \xi^{s} \Lambda_{t, t+s}\left[P_{N t}(f)-M C_{N, t+s}(f)\right] Y_{N, t+s}(f)
\end{aligned}
$$

The stochastic discount factor between $t$ and $t+s$ is given by $\Lambda_{t, t+s}=\beta_{t+s}\left(\frac{C_{t+s}}{C_{t}}\right)^{-1}\left(\frac{P_{t}}{P_{t+s}}\right)$.

Intermediate goods firms maximize (5) subject to the demand for their products (3) and the production function (4). The first order conditions for the optimal prices $P_{H t}^{O}$ and $P_{N t}^{O}$ are:

$$
\begin{aligned}
& E_{t} \sum_{s=0}^{\infty} \xi^{s} \Lambda_{t, t+s}\left[P_{H t}^{O}(f)-\frac{\sigma}{\sigma-1} M C_{H, t+s}(f)\right] Y_{H, t+s}(f)=0 \\
& E_{t} \sum_{s=0}^{\infty} \xi^{s} \Lambda_{t, t+s}\left[P_{N t}^{O}(f)-\frac{\sigma}{\sigma-1} M C_{N, t+s}(f)\right] Y_{N, t+s}(f)=0
\end{aligned}
$$

The price index for each sector evolves according to:

$$
\begin{aligned}
P_{H t} & =\left[\xi P_{H t-1}^{1-\sigma}+(1-\xi)\left(P_{H t-1}^{O}\right)^{1-\sigma}\right]^{\frac{1}{1-\sigma}} \\
P_{N t} & =\left[\xi P_{N t-1}^{1-\sigma}+(1-\xi)\left(P_{N t-1}^{O}\right)^{1-\sigma}\right]^{\frac{1}{1-\sigma}}
\end{aligned}
$$

\subsubsection{Monetary Policy}

Monetary policy follows a simple interest rate rule with partial adjustment:

$$
I_{t}=I_{t-1}^{\rho}\left[\left(\frac{P_{t}}{P_{t-1}}\right)^{\phi_{\pi}}\right]^{1-\rho} e^{\omega_{t}}
$$

In log linear form, this equation is the familiar Taylor rule:

$$
i_{t}=\rho i_{t-1}+(1-\rho) \phi_{\pi} \pi_{t}+\omega_{t}
$$


where $\omega_{t}$ is a monetary policy shock which follows a first order stochastic process:

$$
\omega_{t}=\rho_{\omega} \omega_{t-1}+u_{\omega t}, \quad u_{\omega t} \sim \text { i.i.d.N }\left(0, \sigma_{\omega}^{2}\right)
$$

\subsubsection{Current Account Dynamics and the Real Exchange Rate}

Nominal bond holdings $B_{t}$ evolve according to:

$$
\frac{B_{t}}{P_{t}}=\frac{I_{t-1} B_{t-1}}{P_{t}}+N X_{t}
$$

where $N X_{t}$ is the real value of net exports:

$$
N X_{t} \equiv \frac{P_{H t} Y_{H t}-P_{T t} C_{T t}}{P_{t}}
$$

The current account is the net change in real bond holdings:

$$
C A_{t} \equiv \frac{B_{t}-B_{t-1}}{P_{t}}
$$

The real exchange rate is given by:

$$
Q_{t} \equiv \frac{\varepsilon_{t} P_{t}}{P_{t}^{*}}
$$

\subsubsection{Uncovered Interest Parity Condition}

The foreign country has a similar structure to the home country, but ROW investors can hold a foreign bond in addition to the internationally traded bond. For them to be indifferent between holding these two types of bonds, the uncovered interest parity condition must hold:

$$
E_{t}\left\{I_{t} \frac{\varepsilon_{t+1}}{\varepsilon_{t}} \frac{P_{t}^{*}}{P_{t+1}^{*}}\left(\frac{C_{t+1}^{*}}{C_{t}^{*}}\right)^{-1}\right\}=E_{t}\left\{I_{t}^{*} \frac{P_{t}^{*}}{P_{t+1}^{*}}\left(\frac{C_{t+1}^{*}}{C_{t}^{*}}\right)^{-1} e^{\kappa t}\right\}
$$

$\kappa_{t}$ is a risk premium shock, which follows a first order stochastic process:

$$
\kappa_{t}=\rho_{\kappa} \kappa_{t-1}+u_{\kappa t}, \quad u_{\kappa t} \sim \text { i.i.d.N }\left(0, \sigma_{\kappa}^{2}\right)
$$

In log linear form, the uncovered interest parity condition gives the following relation between real interest rates, real exchange rates and the risk premium shock:

$$
\left(i_{t}-E_{t} \pi_{t+1}\right)=\left(i_{t}^{*}-E_{t} \pi_{t+1}^{*}\right)-\left(E_{t} q_{t+1}-q_{t}\right)+\kappa_{t}
$$

An increase in $\kappa_{t}$ raises the return required by foreign investors to invest in the internationally traded bond. 


\subsubsection{Market Clearing}

For the nontradable sector, production must equal demand:

$$
\begin{aligned}
& Y_{N t}=C_{N t} \\
& Y_{N t}^{*}=C_{N t}^{*}
\end{aligned}
$$

For the home tradable sector, production must equal the sum of the demands by home and foreign consumers:

$$
Y_{H t}=C_{H t}+C_{H t}^{*}
$$

Because domestic bonds are in zero net supply, the sum of nominal holdings of the domestic bond by home and foreign investors must equal zero:

$$
B_{t}+B_{t}^{*}=0
$$

If these conditions are satisfied, Walras' Law ensures clearing in the foreign tradable sector.

\subsection{Robust Sign Restrictions}

\subsubsection{Shocks}

We calibrate the model to study the effects of different shocks. We are interested in distinguishing between two types of shocks: monetary policy and capital inflows. While monetary policy shocks have been widely studied in the literature, the interpretation of capital inflows shocks requires further explanation.

Capital inflows into the US could be driven by different factors. For example, they could result from an increase in savings in ROW, which pushes down long-term world interest rates and leads to an inflow of capital into the US, a deterioration of the US current account and an appreciation of the dollar — the 'savings glut' hypothesis suggested in Bernanke (2005). Alternatively, a monetary policy expansion in ROW would reduce foreign interest rates and increase the relative attractiveness of US assets, leading to capital inflows into the US. These two explanations — 'savings glut' and ROW monetary expansion - point to external factors as explanations for the US current account deficit. An alterative view attributes the deficit to domestic factors, in particular an increase in domestic aggregate demand and a reduction in domestic savings. Our analysis distinguishes between these different sources of capital inflows.

We are interested in identifying separately the effect of US monetary policy shocks and of different types of shocks that generate capital inflows to the US. These shocks would be confounded if an improvement in the US monetary policy framework increased the perceived safety of US assets, encouraging foreign investors to invest more in the US. In that case, capital inflows would 
be driven by monetary policy and it would not be possible to separate them. To address this issue, we separately identify a risk premium shock, which captures changes in the perceived safety of US assets as a result of a decline in macroeconomic risk due to the 'great moderation', for example. By doing this, we are able to control for capital inflows that are driven by improvements in the monetary policy framework. The component of capital inflows that is left is not driven by monetary policy and we are able to do a 'horse race' between monetary policy and capital inflows shocks and separate their contribution to the housing boom ${ }^{1}$.

To summarize, we calibrate the theoretical model and derive impulse responses to five types of shocks:

1. Expansionary monetary policy shock in the US. This is a negative shock to $\omega_{t}$ in equation (6).

2. Reduction in aggregate demand in $R O W$. This is the 'savings glut' shock and can be seen as a positive shock to $\varsigma_{t}$ in ROW, which increases the discount factor and makes ROW households more patient.

3. Expansionary monetary policy shock in $R O W$. This is a negative shock to $\omega_{t}$ in ROW.

4. Increase in aggregate demand in the US. This can be seen as a negative shock to $\varsigma_{t}$ in the US, which reduces the discount factor and makes US households more impatient.

5. Risk premium shock. This is a shock that increases the perceived safety of US assets. It can be seen as a reduction in $\kappa_{t}$ in equation (7), i.e., a reduction in the real interest rate that investors require in order to invest in the US.

\subsubsection{Parameter Ranges}

To derive robust implications from the theoretical model for each of these shocks that are not sensitive to variations in the structural parameters, we follow the approach in Peersman and Straub (2009) and Pappa (2009) and define a range for each of the structural parameters based on the empirical literature. The intervals for all parameter values are reported in Table 1. Most intervals are uncontroversial and contain the values used in the calibration in Ferrero, Gertler and Svensson (2007). We assume shocks to aggregate demand and the risk premium shock to be quite persistent, as they represent structural preference parameters and are likely to persist over time. We assume a smaller degree of persistence for monetary policy shocks. The model is calibrated to match quarterly dynamics.

\footnotetext{
${ }^{1}$ Fogli and Perri (2008) document a positive correlation between changes in output volatility and changes in the net foreign asset position in OECD countries. They construct a model where a reduction in business cycle volatility leads to a reduction in precautionary savings and a permanent deterioration in the net foreign asset position. Our risk premium shock captures this mechanism.
} 
Table 1. Parameter values and ranges

\begin{tabular}{lll}
\hline \hline Parameter & Description & Range \\
\hline$\gamma$ & Preference share for tradables & $0.1-0.3$ \\
$\alpha$ & Preference share for home tradables & $0.6-0.9$ \\
$\eta$ & Elasticity of substitution between home and foreign tradables & $1.5-3$ \\
$\mu$ & Elasticity of substitution between tradables and nontradables & $0.5-1.5$ \\
$\varphi$ & Inverse of Frisch elasticity of labour supply & $1.5-2.5$ \\
$\sigma$ & Elasticity of substitution between intermediate inputs & $6-11$ \\
$\xi$ & Probability that price does not adjust & $0.5-0.75$ \\
$\rho_{\varsigma, H}$ & Persistence of preference shock at home & $0.95-0.99$ \\
$\rho_{\varsigma, F}$ & Persistence of preference shock in ROW & $0.95-0.99$ \\
$\rho_{\kappa}$ & Persistence of risk premium shock & $0.95-0.99$ \\
$\rho_{\omega, H}$ & Persistence of monetary shock at home & $0.4-0.7$ \\
$\rho_{\omega, F}$ & Persistence of monetary shock in ROW & $0.4-0.7$ \\
$\rho$ & Smoothing coefficient in Taylor rule & $0.5-0.9$ \\
$\phi_{\pi, H}$ & Response to CPI in Taylor rule at home & $1.5-3$ \\
$\phi_{\pi, F}$ & Response to CPI in Taylor rule in ROW & $1.5-3$ \\
\hline \hline
\end{tabular}

\subsubsection{Dynamics}

Having defined a sensible range of parameter values, we use the model to produce impulse responses for each shock. We assume that the parameters are uniformly distributed over the selected parameter range. We then draw a random value for each parameter from that range and calculate the impulse response functions. We report the median and the 16th and 84th percentiles of the impulse responses.

Figure 4 (a) reports theoretical impulse responses for a US monetary policy expansion in which the US nominal short term interest rate decreases by about one percentage point ${ }^{2}$. The findings are in line with well-known results in the literature. In particular, we find that a reduction in nominal short term interest rates in the US increases consumption and prices. This is consistent with the findings in Canova and de Nicoló (2002) who show that, under a variety of different models, output and prices rise following an expansionary monetary policy shock. We choose to focus on consumption and not output in order to separate the effect on domestic absorption and on net exports (which is captured by the current account). The reduction in US interest rates increases the attractiveness of investment in ROW, leading to outflows of capital from the US. As a result, the US current account improves and the dollar depreciates. The inflows of capital into ROW generate an increase in foreign consumption.

\footnotetext{
${ }^{2}$ The size of the shocks is calibrated as follows. For shocks that generate a US current account deficit, we calibrate them to generate a deficit of about $15 \%$ of tradable output. This is equivalent to a deficit of about $4 \%$ of GDP, which matches the current situation. For shocks that do not generate a current account deficit (for example, a US monetary expansion), we calibrate them to generate an increase in US consumption of about $2 \%$, which equals the increase originated by a 'savings glut' shock.
} 
There is a significant amount of empirical work testing the effects of monetary shocks on the exchange rate and the current account. Eichenbaum and Evans (1995) find that a contractionary monetary policy shock in the US leads to a persistent and significant appreciation of the dollar. Zettelmeyer (2004) confirms this for Australia, Canada and New Zealand. Betts and Devereux (2001) estimate VARs on US and G7 variables and identify monetary shocks using a Choleski decomposition. They find that expansionary monetary shocks generate an exchange rate depreciation. Lane (2001) focuses on the effect on the current account using long run restrictions. He finds that the current account initially deteriorates following a monetary expansion, but quickly starts to improve and moves into surplus after about a year. Prasad (1999) estimates a structural VAR for G7 countries and also identifies monetary policy shocks using long run restrictions. He finds that a monetary expansion leads to an exchange rate depreciation and an improvement in the current account. Lee and Chinn (2006) confirm this finding in a VAR for 67 countries. Bems et al (2007) estimate a VAR for the US and identify monetary shocks using a Choleski decomposition. They confirm that a monetary expansion leads to a depreciation of the exchange rate, but find that it also causes a deterioration in the current account. Barnett and Straub (2008) arrive at a similar conclusion using a VAR with sign restrictions. While these studies point to an unambiguous effect of monetary policy shocks on the exchange rate, the effect on the current account is uncertain. For this reason, we do not impose any sign restrictions on the response of the current account and rely on other variables for identification. 
Theoretical impulse responses

Figure 4 (a) US monetary policy expansion
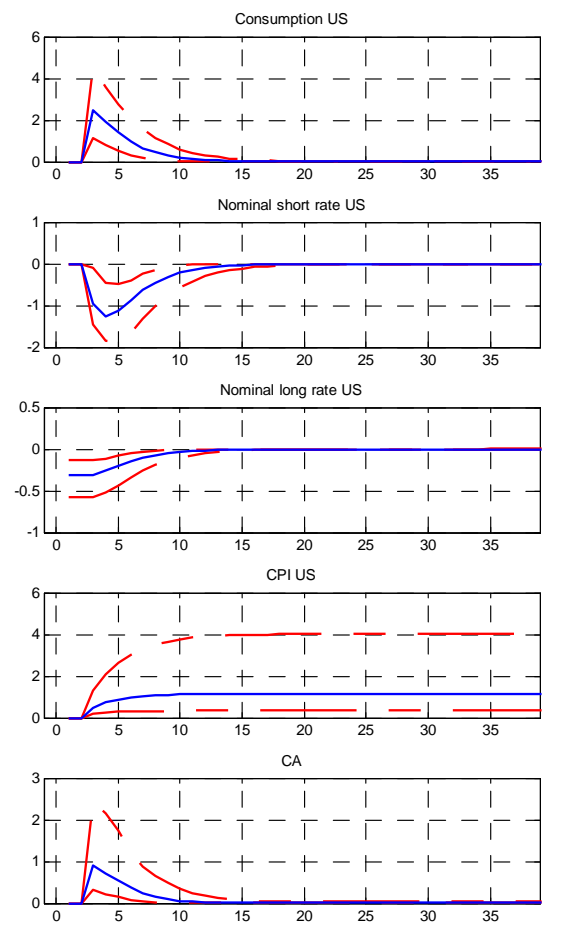
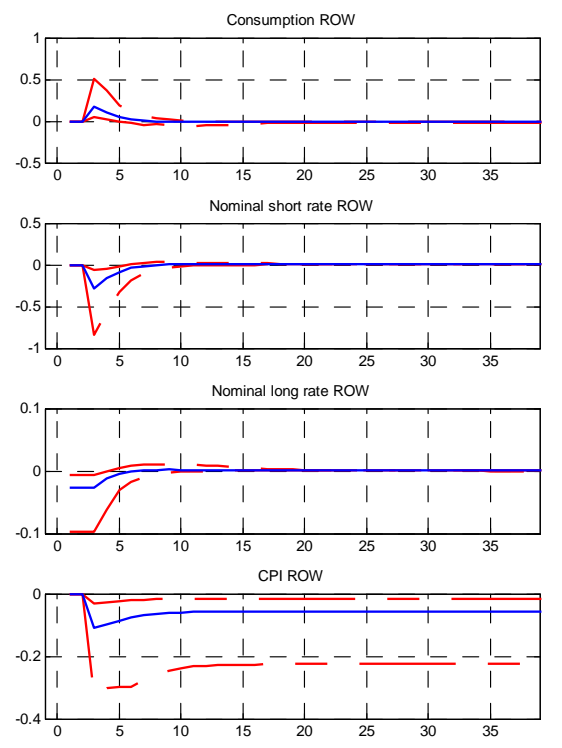

Nominal exchange rate

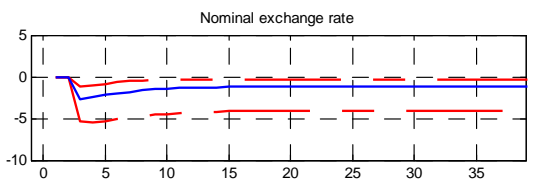

Turning now to different types of capital inflows shocks, Figure 4 (b) reports theoretical impulse responses following a negative shock to aggregate demand in ROW — 'savings glut' shock. The increase in the degree of patience of foreign households leads to a reduction in consumption and an increase in savings in ROW. The extra savings are partly allocated to US assets, generating an increase in consumption in the US, a current account deficit and an appreciation of the dollar. Long term interest rates decrease both in the US and in ROW in response to the increase in global savings.

These results are consistent with the predictions of the model developed in Caballero et al (2008). Their model contains two regions: the US and the rest of the world. These two regions are initially symmetric and have the same degree of financial development, i.e. the same capacity to generate financial assets from real investments. The model can be used to analyze the implications of two phenomena: a reduction in the degree of financial development in the rest of the world following, for example, a collapse in its asset markets; and a gradual integration and emergence of fast growing economies in the rest of the world. Both phenomena have the same implications, generating a current account deficit in the US and a decline in long term interest rates. The dollar appreciates in the short run and depreciates gradually until it stabilizes in the long run.

Similar qualitative predictions are obtained in Sá and Viani (2010), who use a general equilibrium model to simulate the implications of a reduction in the preference of foreign investors for 
US assets, i.e. a reduction in capital inflows. Their model shows that, if foreign investors invest a smaller share of their wealth in dollar assets, the dollar would depreciate in the short run and the current account would improve. The price of US assets would fall and the return would increase. These predictions are identical to the ones we obtain but with opposite signs, since we study the effect of an increase rather than a reduction in capital inflows to the US.

Figure 4 (b). Reduction in aggregate demand in ROW

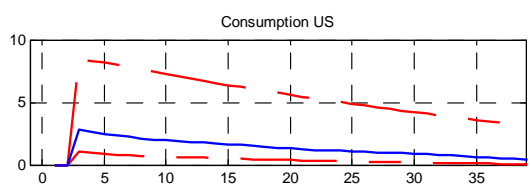

Nominal short rate US

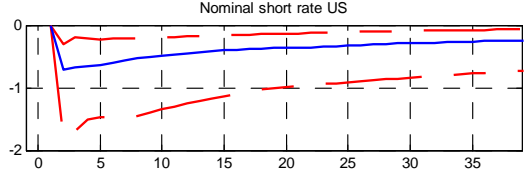

Nominal long rate US

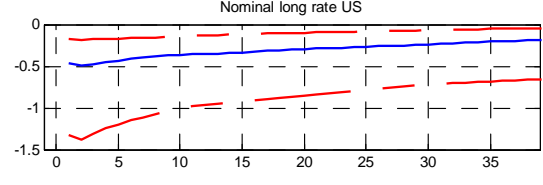

CPIUS
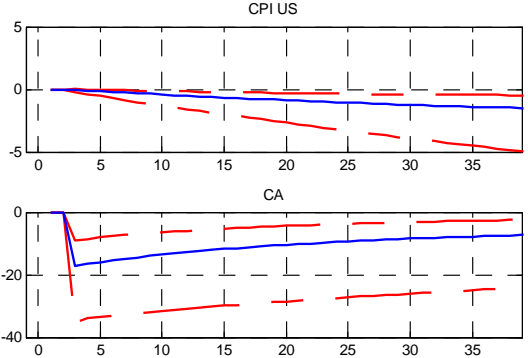

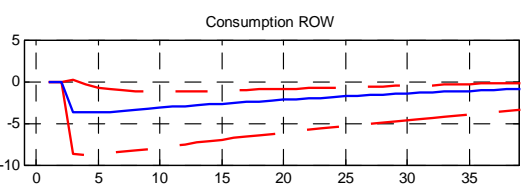

Nominal short rate ROW
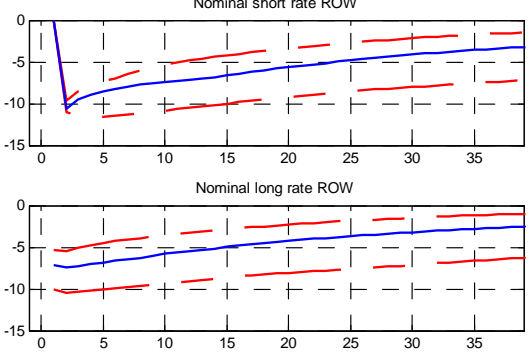

CPI ROW

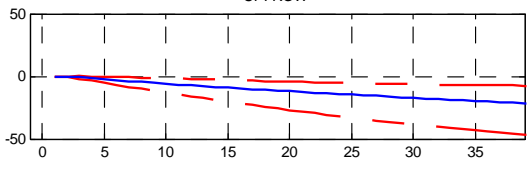

Nominal exchange rate

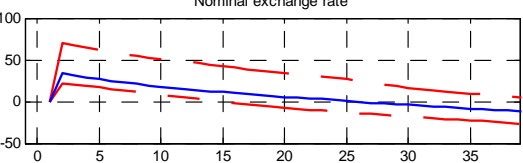

Another external factor which could explain an increase in capital inflows to the US would be a monetary policy expansion in ROW. The theoretical impulse responses for this shock, reported in Figure 4 (c), are the mirror image of the ones reported in Figure 4 (a) for a US monetary expansion. The shock increases consumption and prices in ROW. The reduction in interest rates in ROW increases the attractiveness of investment in US assets, leading to capital inflows to the US and an appreciation of the dollar. The inflow of capital fuels an increase in consumption in the US. 
Figure 4 (c). ROW monetary policy expansion
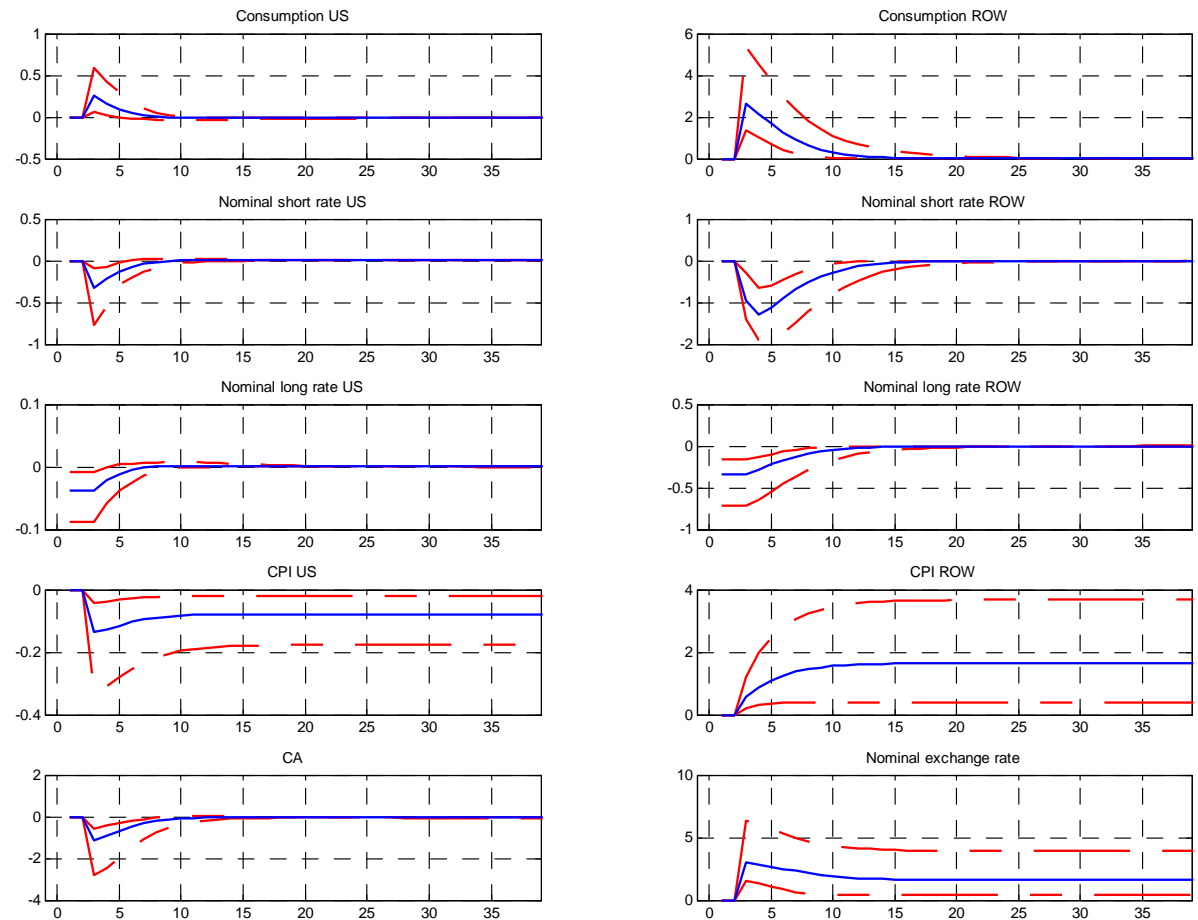

Figure 4 (d) reports theoretical impulse responses for a positive shock to aggregate demand in the US, which provides a domestically-driven explanation for the current account deficit. The shock makes US households less patient, which reduces savings and increases consumption. US investors who had part of their savings invested in ROW assets will sell some of those assets in order to increase consumption. This increases the US current account deficit and generates an appreciation of the dollar. The outflow of capital from ROW leads to a reduction in foreign consumption. Interest rates in the US and ROW increase in response to the reduction in US savings. 
Figure $4(\mathrm{~d})$. Increase in aggregate demand in the US
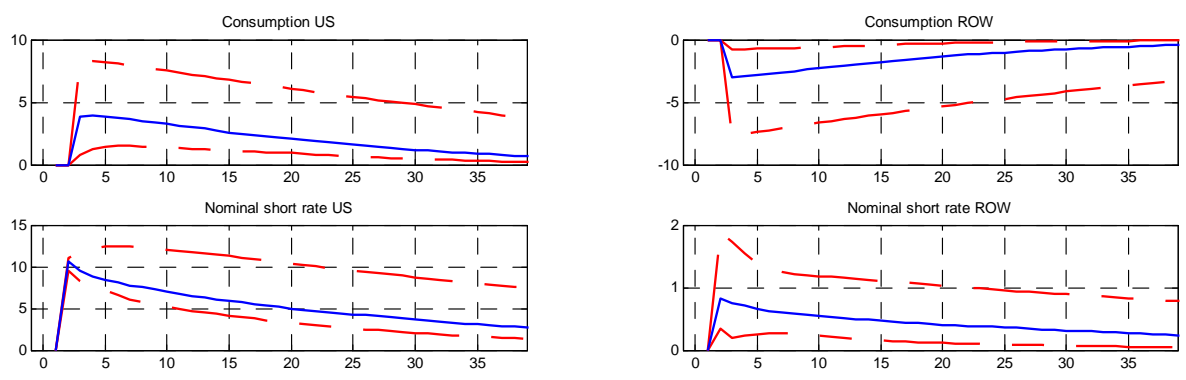

Nominal long rate US
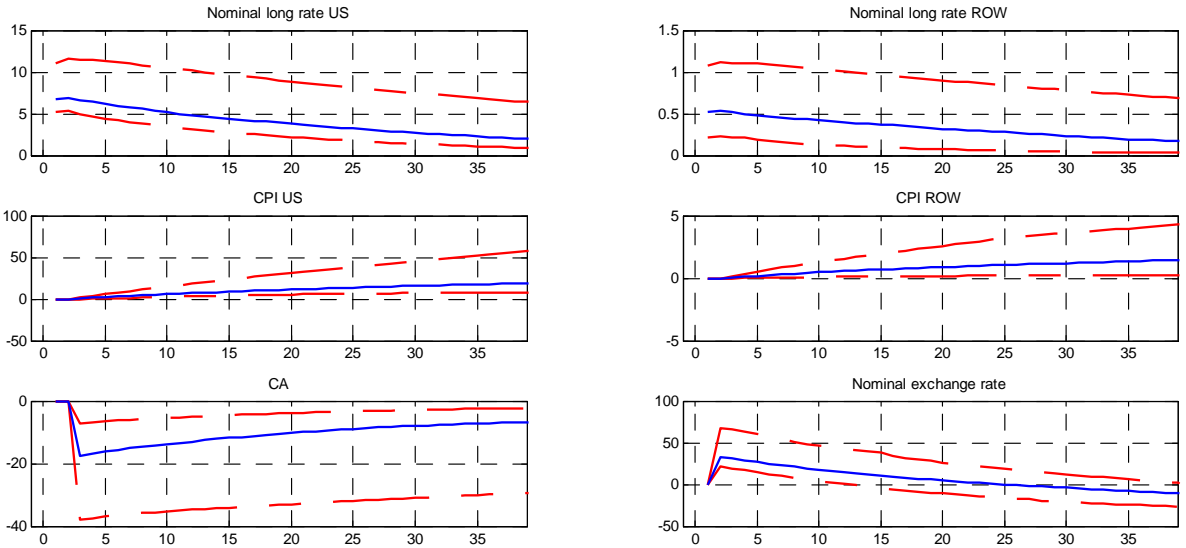

We now turn to the risk premium shock. As discussed above, this shock is introduced to ensure that we can separate monetary policy and capital flows shocks. It may be the case that capital inflows to the US are driven by an improvement in its monetary policy framework, which generates an environment of low and stable inflation and reduces the risk premium required by foreigners to invest in the US. This is empirically plausible since the US did experience a period of low and stable inflation — the 'great moderation' — before the global financial crisis.

Figure 4 (e) reports theoretical impulse responses following a shock that reduces the risk premium required by foreigners to invest in US assets. The increase in the perceived safety of US assets encourages foreign investors to reallocate part of their savings from domestic assets into US assets. This redistributes resources away from ROW into the US, leading to a reduction in consumption in ROW and an increase in consumption in the US. The increase in capital inflows in the US generates a current account deficit and an appreciation of the dollar. Interest rates decrease in the US and increase in ROW reflecting the increase in demand for US assets and the reduction in demand for ROW assets. 
Figure 4 (e). Risk premium shock
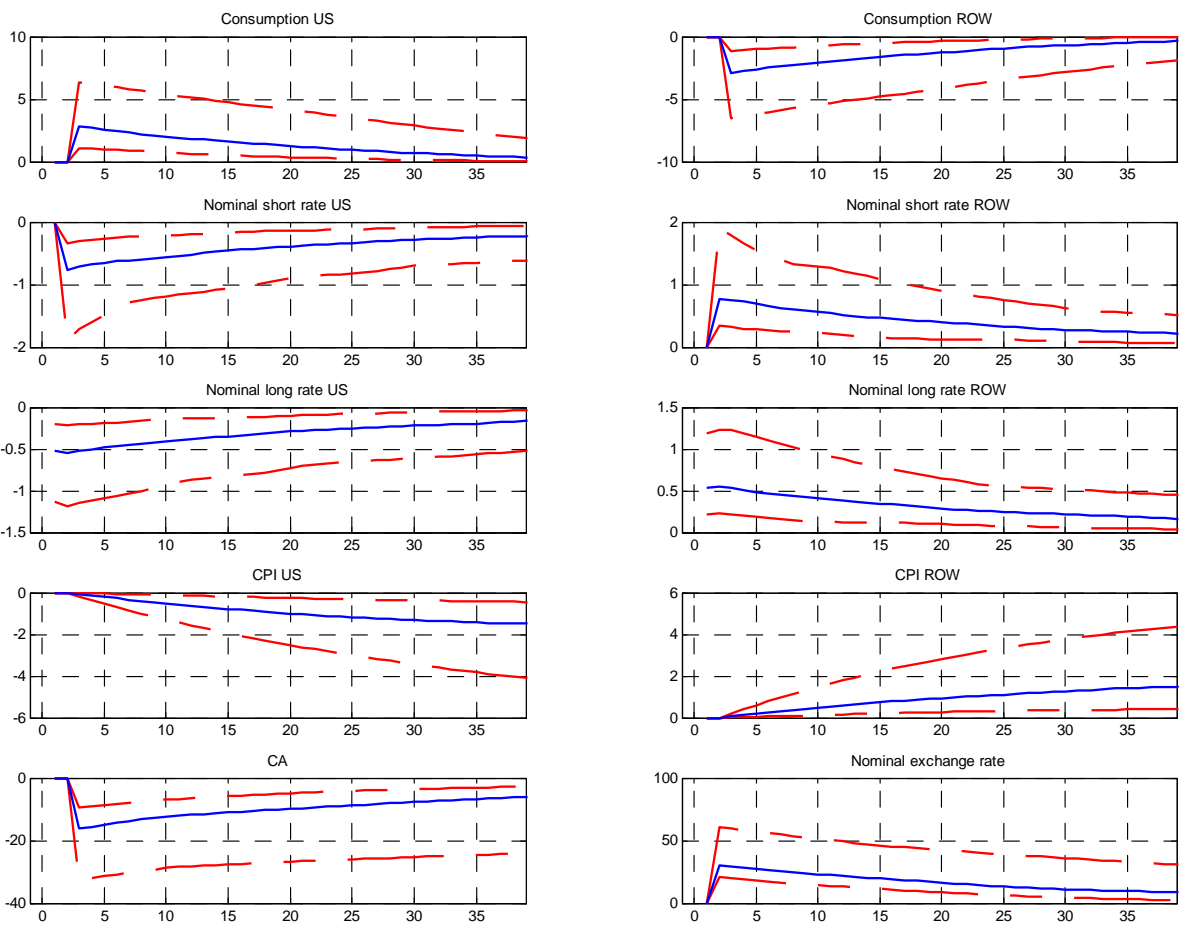

Table 2 summarizes the sign restrictions that will be used in the empirical model to identify the shocks. The predictions of the model are sufficient to distinguish between all five shocks that we are considering, since there is at least one common and one different sign restriction for each pair of shocks. We allow for a possible zero impact of the shocks since the restrictions are imposed as $\leq$ or $\geq$. The restrictions are imposed on impact and for two quarters after the shock.

Table 2. Sign restrictions

\begin{tabular}{llllll}
\hline \hline Variables/shock & US monetary expansion & Reduction in ROW AD & ROW monetary expansion & Increase in US AD & Risk premium \\
\hline US consump & $\geq 0$ & $\geq 0$ & $\geq 0$ & $\geq 0$ & $\geq 0$ \\
ROW consump & $\geq 0$ & $\leq 0$ & $\geq 0$ & $\leq 0$ & $\leq 0$ \\
US short rate & $\leq 0$ & & $\leq 0$ & \\
ROW short rate & & $\leq 0$ & $\leq 0$ & $\geq 0$ & $\leq 0$ \\
US long rate & $\leq 0$ & $\leq 0$ & & $\geq 0$ & $\geq 0$ \\
ROW long rate & & & $\geq 0$ & & \\
US CPI & $\geq 0$ & $\leq 0$ & & $\leq 0$ & $\leq 0$ \\
ROW CPI & & $\geq 0$ & $\geq 0$ & $\geq 0$ & $\geq 0$ \\
Current account & & & & \\
Exchange rate & $\leq 0$ & &
\end{tabular}

Note that the restriction on the long term nominal interest rate for monetary policy shocks does 
not necessarily follow from theory. We impose this restriction in order to avoid giving an advantage to 'savings glut' shocks in the 'horse race' to explain the housing boom. Because long term interest rates fall with a 'savings glut' shock and these are the rates that determine the cost of housing loans, if we did not impose this restriction for monetary policy shocks we would be increasing the chances of 'savings glut' shocks explaining most of the variation in the housing variables. We therefore impose this restriction for monetary policy shocks as well and retain only those shocks that do not lead to an increase in long term nominal interest rates.

\section{Econometric Framework}

\subsection{Reduced Form Model and Data}

We estimate the following open economy vector autoregressive (VAR) model:

$$
Y_{t}=c+\sum_{k=1}^{L} A_{i} Y_{t-k}+u_{t} \quad t=1, \ldots T \quad u_{t}^{\sim} N(0, \Sigma)
$$

where $c$ is a constant term, $L$ is the lag length, $Y_{t}$ is a vector of endogenous variables, $A_{i}$ is a matrix of coefficients and $u_{t}$ is the error term. The vector $Y_{t}$ contains twelve endogenous variables. Ten of these variables are used to identify the shocks: short term and long term nominal interest rates in the US and ROW, real household consumption expenditure and the CPI in the US and ROW (in logs), the ratio of the US current account balance to GDP, and the dollar nominal tradeweighted exchange rate (in logs). The other two variables are used to capture developments in the housing market: real residential investment (in logs), and an index of real house prices (in logs) deflated by the GDP deflator. The model is estimated with two lags on quarterly data from 1979 Q1 to 2006 Q4.

Table 3 lists the variables and data sources. Data on interest rates and the CPI are from the dataset constructed in Pesaran, Schuermann and Smith — PSS (2008) ${ }^{3}$. Data on real household consumption expenditure is constructed using the share of (nominal) household consumption expenditure to GDP from the IMF International Financial Statistics (IFS) multiplied by the level of real GDP from PSS (2008). ROW variables are constructed as a trade-weighted average of the 32 countries (excluding the US) in the PSS (2008) dataset ${ }^{4}$. Private residential investment is obtained from the Federal Reserve Economic Data (FRED) and house prices are measured by the national house price index constructed by the Federal Housing Finance Agency (FHFA, previously called

\footnotetext{
${ }^{3}$ These data can be downloaded from

http://www.econ.cam.ac.uk/faculty/pesaran/fp09/Data_and_Codes_For_PSS_Rejoinder.zip.

${ }^{4}$ We have also estimated the model using GDP weights to construct the ROW variables and the results are qualitatively robust. We use three sets of weights: an average over the period 1980Q1 to $1982 \mathrm{Q} 4$ to be used at the start of the sample (from 1979Q1 to 1986Q4); an average over the period 1991Q1 to 1993Q4 to be used at the middle of the sample (from 1987Q1 to 1997Q4); and an average over the period 2002Q1 to 2004Q4 to be used at the end of the sample (from 1998Q1 to 2006Q4). This combines the simplicity of fixed weights with the up-to-date nature of time-varying weights. As discussed in Dees et al (2007), trade weights that vary continuously could mask the underling movements of the macroeconomic variables that go into the construction of the ROW variables.
} 
OFHEO). Both variables are deflated by the GDP deflator. The FHFA house price index is a repeated-sales index, measuring average price changes in repeated sales or refinancings on the same properties. The use of repeated transactions helps to control for differences in the quality of the properties included in the sample. For this reason, the index is described as a "constant quality" house price index. It includes single-family properties whose mortgages have been purchased or securitized by Fannie Mae or Freddie Mac since January 1975. The evolution of this index is plotted in Figure 1, which shows that house prices have substantially increased since the late 1990s.

Table 3. Variables and data sources

\begin{tabular}{ll}
\hline \hline Variable & Source \\
\hline Short term interest rate (3 month) US & PSS (2008) \\
Short term interest rate (3 month) ROW & PSS (2008) \\
Long term interest rate (10 year) US & PSS (2008) \\
Long term interest rate (10 year) ROW & PSS (2008) \\
Real household consumption expenditure US & PSS (2008) and IMF IFS \\
Real household consumption expenditure ROW & PSS (2008) and IMF IFS \\
CPI US & PSS (2008) \\
CPI ROW & PSS (2008) \\
Ratio of US current account balance to nominal GDP & OECD Economic Outlook \\
Dollar nominal effective exchange rate & IMF IFS \\
Real residential investment & FRED, code PRFI, deflated by GDP deflator \\
Real house price index & FHFA index deflated by GDP deflator \\
\hline \hline
\end{tabular}

Open economy VAR models typically have a large number of coefficients to be estimated. Previous work deals with the large dimension of the model by specifying it in differences between home and foreign variables - for example, Farrant and Peersman (2006) and Corsetti, Dedola and Leduc (2009). This implicitly assumes symmetry across regions and creates a problem with the interpretation of the shocks. For example, if we observe a shock which reduces relative short term interest rates, increases relative consumption and prices and leads to a relative depreciation, we would not be able to distinguish whether this is an expansionary monetary policy shock at home or a contractionary monetary policy shock abroad. Another way of dealing with the large dimension of the model is to identify the shocks individually, without requiring them to all be present in the data and be orthogonal to each other, as in Corsetti, Dedola and Leduc (2009). This approach is problematic because the impulse responses for one of the shocks could be capturing the effect of some other shock.

To get around these issues, we use an explicit Bayesian prior to deal with the dimensionality problem. In particular, we use the prior suggested in Litterman (1986), often referred to as the Minnesota prior. Banbura, Gianonne and Reichlin (2007) provide an intuitive explanation for this type of prior and show that its application to large Bayesian VARs results in good forecasting performance. 
The basic principle behind the Minnesota prior is that the variables in the VAR are 'centered' around a random walk with a drift so that the prior mean can be associated with the following representation for $Y_{t}$ :

$$
Y_{t}=c+Y_{t-1}+u_{t}
$$

This corresponds to shrinking the diagonal elements of $A_{1}$ in model (8) towards one and shrinking the off-diagonal coefficients as well as the coefficients in $A_{2}, \ldots, A_{L}$ towards zero ${ }^{5}$. This prior is appropriate for variables that show a high degree of persistence, but is not appropriate for variables believed to be characterized by substantial mean reversion. Therefore, for short and long term interest rates and the exchange rate we impose the prior of white noise by setting the prior mean equal to zero.

\subsection{Identification of the Shocks}

To identify the shocks in the data, we use the sign restrictions derived from the theoretical model and reported in Table 2. We are interested in identifying two types of shocks: an expansionary monetary policy shock and an increase in capital flows to the US.

The common identification problem in VAR models is that some restrictions need to be imposed on the covariance matrix in order to identify the structural shocks. Model (8) is the reduced form version of the structural model, where innovations are given by the vector $v$, with $E\left(v v^{\prime}\right)=I$. What is needed is to find a matrix $B$ such that $u_{t}=B v_{t}$, where the $j$ th column of $B$ represents the immediate impact on all variables of the $j$ th structural shock, one standard error in size. The only restriction on $B$ comes from the variance-covariance matrices of the reduced and structural form shocks:

$$
\Sigma=E\left(u_{t} u_{t}^{\prime}\right)=E\left(B v_{t} v_{t}^{\prime} B^{\prime}\right)=B B^{\prime}
$$

This leaves many degrees of freedom in specifying $B$ and hence further restrictions are necessary to achieve identification. The usual methodology is to impose a certain ordering on the sequencing of shocks - Choleski decomposition. This corresponds to imposing zero restrictions on the contemporaneous interactions between variables, for example assuming that output does not respond contemporaneously to changes in interest rates. But theory does not always provide guidance on what the ordering should be.

Many studies have appealed to the reasonableness of the impulse responses as an 'informal' identification criterion and choose an ordering which delivers results consistent with conventional wisdom. However, it is preferable to be explicit about the identifying restrictions. This can be achieved with the method developed by Canova and de Nicoló (2002), Faust and Rogers (2003) and

\footnotetext{
${ }^{5}$ To set the shrinkage parameter, we follow the approach in Banbura, Gianonne and Reichlin (2008) and choose it such that the in-sample fit of the model is the same found with a 'smaller' VAR. We estimate two smaller VARs: one with short term and long term interest rates and another with the short term interest rate and the ratio of the US current account balance to GDP. Both give a shrinkage parameter of about 0.09. We have also estimated the model with a looser prior, using a shrinkage parameter of 0.12 , and the results are qualitatively robust.
} 
Uhlig (2005) of imposing sign restrictions on the impulse responses. The idea is to rely on economic theory to derive 'reasonable' signs for the impulse responses. We use the sign restrictions derived from the theoretical model in Section 2. We choose different matrices $B$ which satisfy condition (9) and, for each choice of $B$, generate the implied impulse response functions. Finally, we check whether the sign restrictions are satisfied and keep the impulse responses which satisfy the sign restrictions ${ }^{6}$.

To strike a balance between relying on theory to select impulse responses that look 'reasonable' and allowing the data to speak for itself, we impose a parsimonious set of sign restrictions. In particular, we do not impose any restrictions on the responses of real residential investment and real house prices, which are the variables we chose to capture developments in the housing market. Instead, we leave them unrestricted and rely on the other variables for identification.

\section{Empirical Evidence}

\subsection{Baseline Results}

Figure 5 shows the impulse responses over five years obtained from estimating model (8) using the sign restrictions in Table 2. The solid vertical lines indicate the responses for which sign restrictions were imposed. We plot the median and the 16th and 84th percentiles of the posterior distribution of impulse responses. If the distribution was normal, these percentiles would correspond to a one standard deviation band.

\footnotetext{
${ }^{6}$ We have repeated the algortithm until we keep 100 impulse responses for each of the shocks. The results with an acceptance threshold of 1000 are very similar.
} 
Figure 5. Empirical impulse responses

US monetary policy expansion
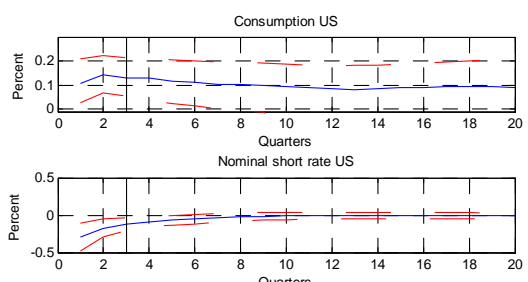

Quarters
Nominal long rate US

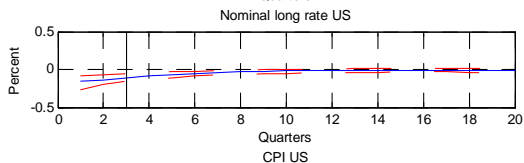

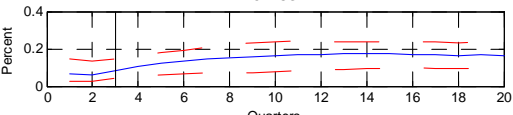
Quarters
Current Account

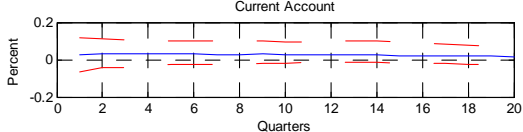

US real residential investment

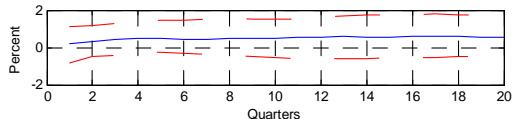
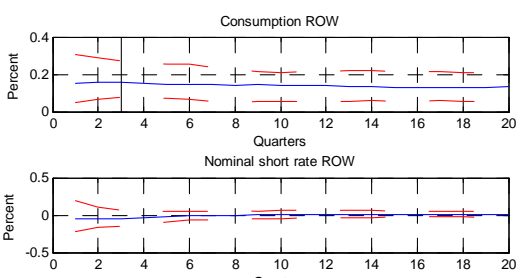

Nominal long rate Row
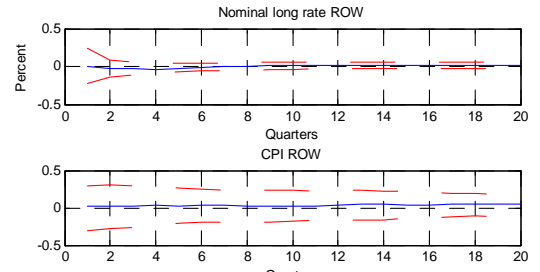

Nominarters

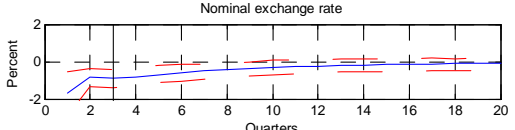

US real house prices

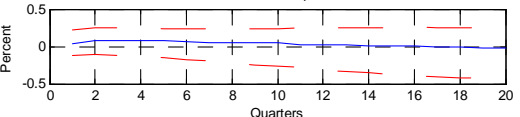

Reduction in aggregate demand in ROW

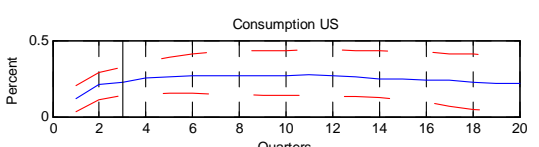

Nominal short rate US

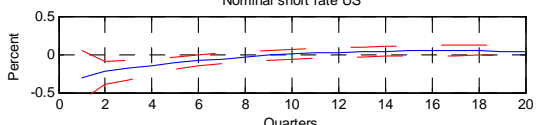

Nominal long rate US

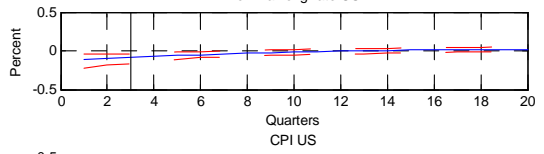

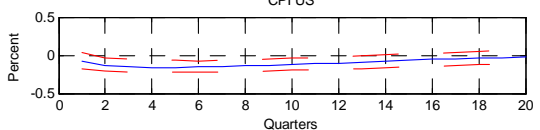
Current Account

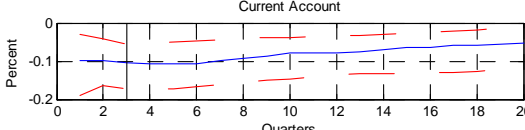

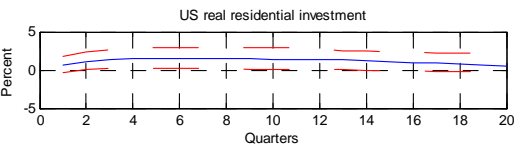

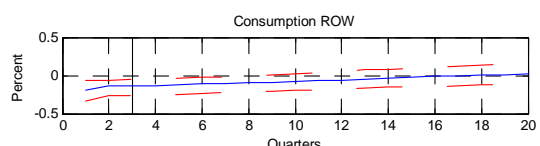
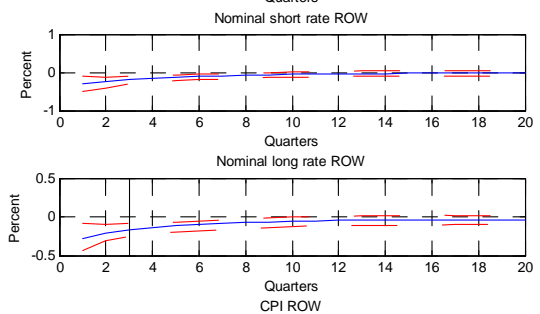

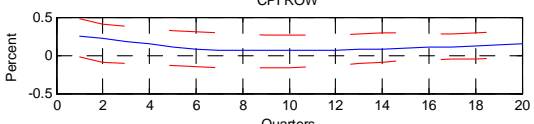

Nominal exchange rate

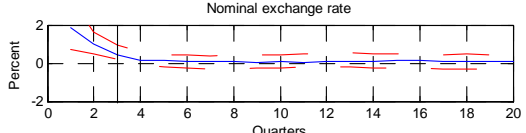

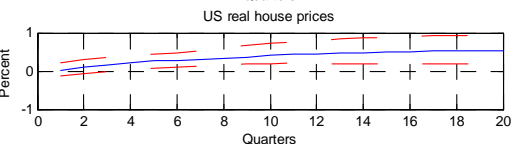


ROW monetary policy expansion

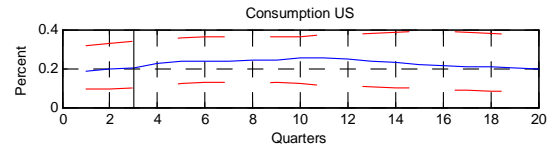

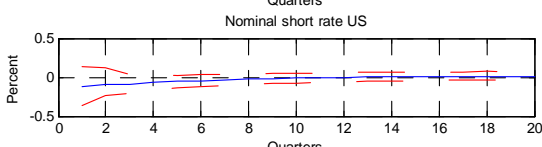
Quarters
Nominal long rate US

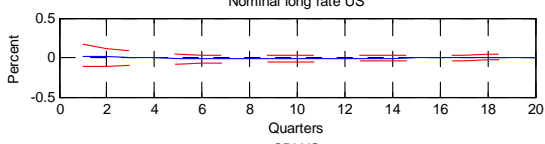

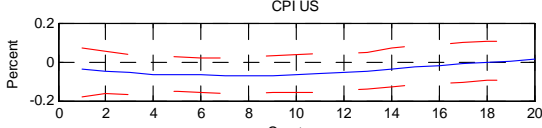
Quarters
Current Account
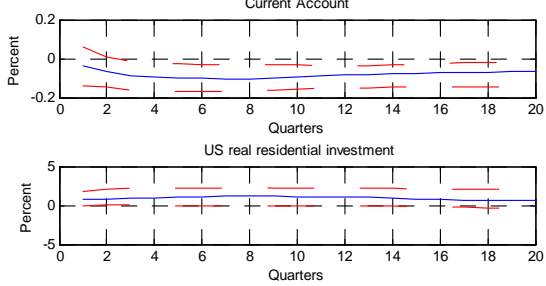

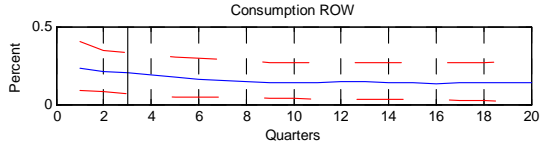

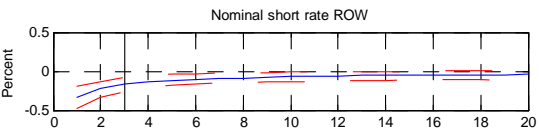
Quarters
Nominal long rate ROW

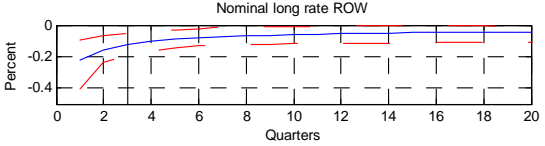

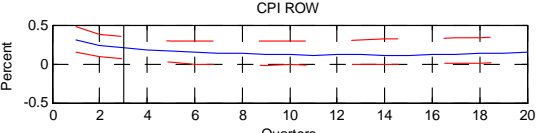

Nominal exchange rate
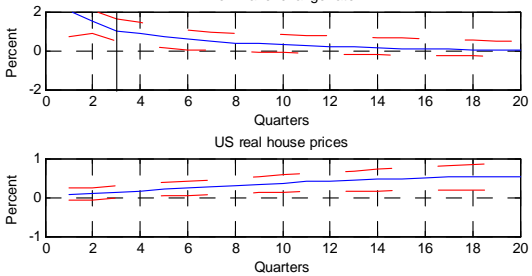

Increase in aggregate demand in the US
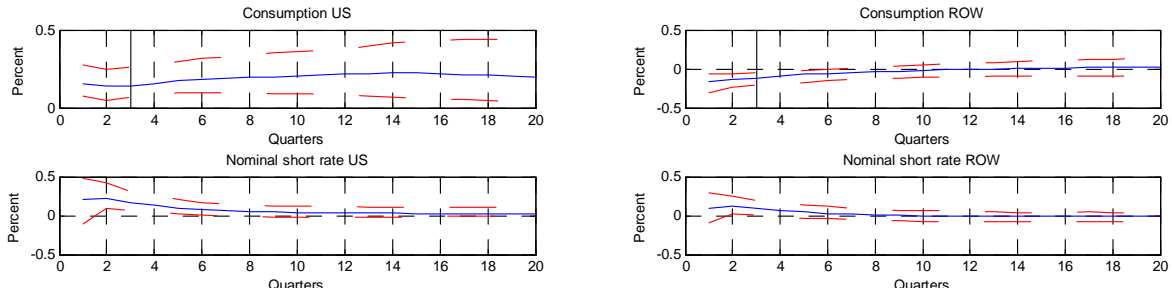

Nominal long rate US

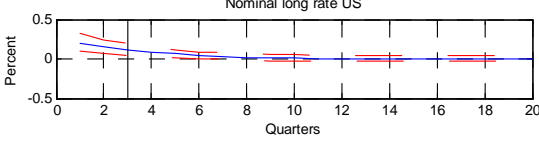

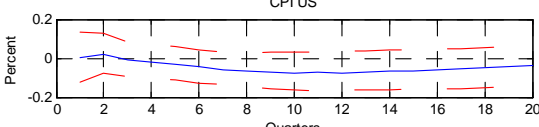
Quanters
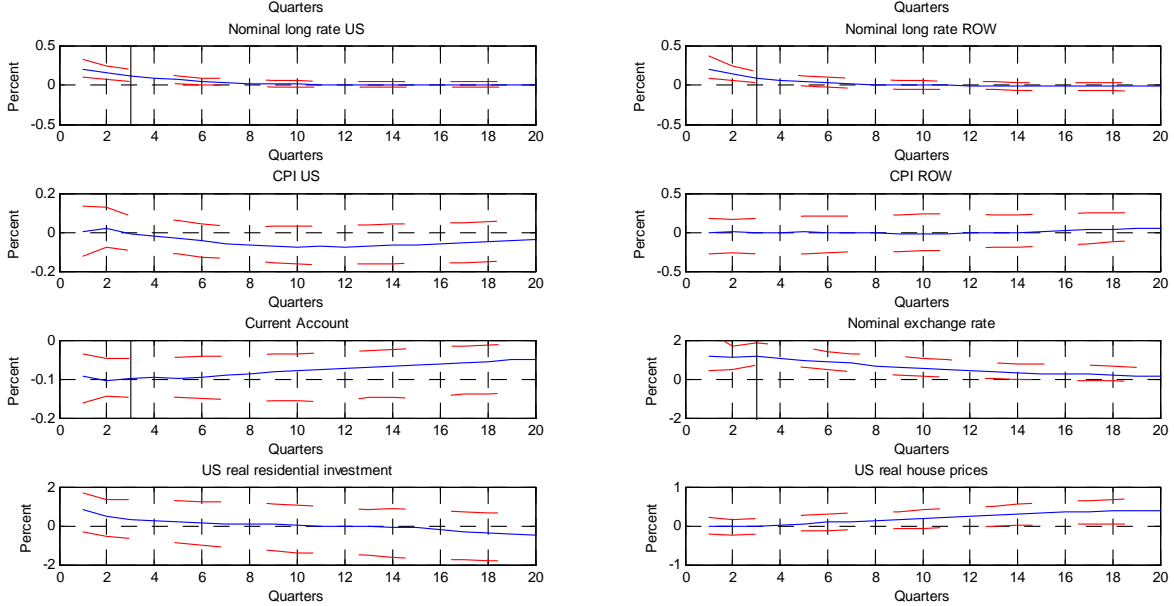

US real house prices

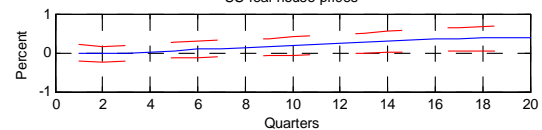


Risk premium shock
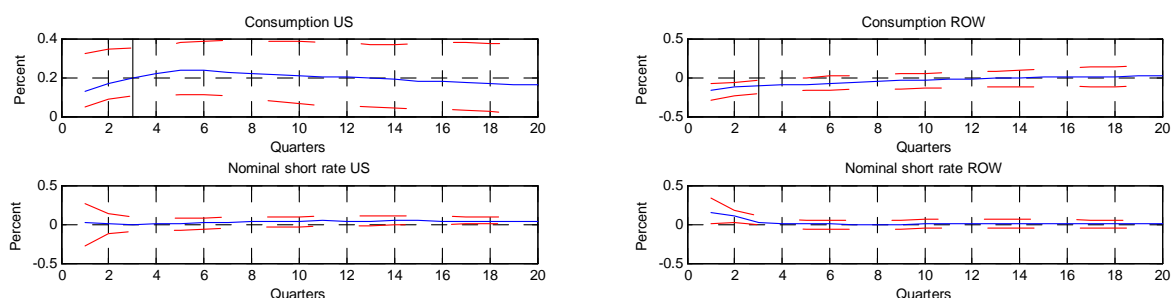

Nominal long rate US
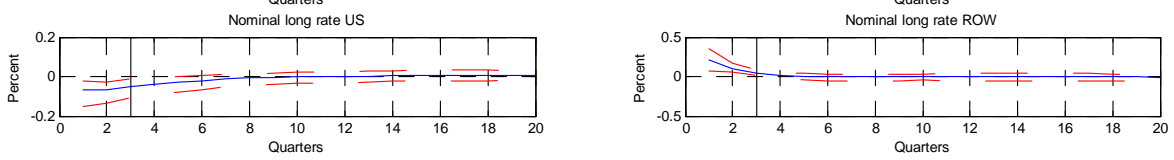

CPIUS

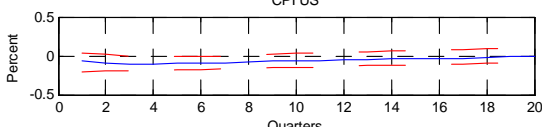

CPIROW

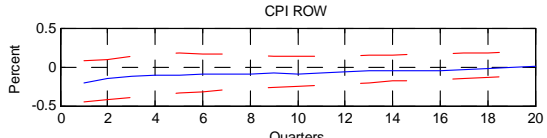

Current Accoun
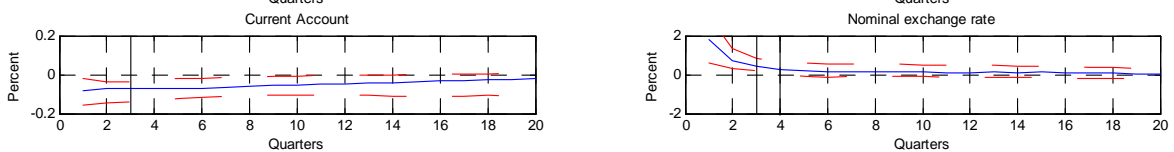

US real residential investment
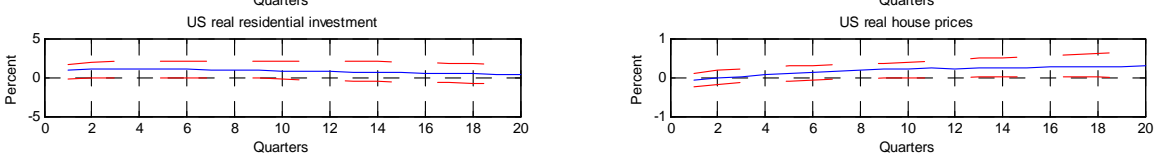

US monetary policy shocks do not seem to have a significant effect on real residential investment or real house prices, with zero lying within the posterior coverage intervals? ${ }^{7}$. By contrast, 'savings glut' shocks lead to a significant increase in real residential investment and real house prices. The increase in real residential investment peaks at about $1.5 \%$ six quarters after the shock and is quite persistent. The increase in real house prices is also very persistent and is equal to about $0.52 \%$ five years after the shock. A monetary expansion in ROW also seems to have a positive effect on real residential investment and real house prices. Positive shocks to aggregate demand in the US should not have a large effect on housing variables since they lead to an increase in long term interest rates, pushing up the cost of borrowing. Indeed our results show that these shocks have no significant effect on real residential investment and have a positive but largely insignificant effect on real house prices. Finally, shocks which reduce the risk premium required by foreigners to invest in US assets also have a positive but largely insignificant effect on real residential investment and house prices.

These results suggest that US monetary policy played a limited role in the housing boom that occurred in the run up to the global financial crisis. The housing boom is better explained by looking at shocks that generated an increase in capital inflows to the US. Among these shocks, an

\footnotetext{
${ }^{7}$ This result appears inconsistent with previous studies which found a significant effect of monetary policy on house prices - for example, Iacoviello (2005) and Jarociński and Smets (2008). However, it should be noted that most of these studies rely on zero restrictions for identification of monetary policy shocks, whereas our identification relies only on sign restrictions. Using a framework more comparable to ours, Del Negro and Otrok (2007) find a significant but small effect of monetary policy shocks on residential investment and house prices using a VAR in first differences. Their model estimated in levels delivers even smaller effects.
} 
increase in savings in ROW — 'savings glut' — played a particularly important role. An increase in real house prices of $0.52 \%$ may seem small, given that house prices doubled in the period from 1990 to 2007. However, we should note that, because the coefficients in the model are time invariant, the impulse responses show the effect of the shocks on average over the whole sample period. It could be that 'savings glut' shocks have become more important from the mid-1990s as a result of financial globalization. Also, we are simulating the responses to a one-time shock. With repeated shocks over time, the cumulative response would be larger. In our view, the message to be taken from these impulse responses is that 'savings glut' shocks provide a better explanation to the housing boom than US monetary policy and other shocks that lead to capital inflows to the US.

One way of comparing the relative contributions of different types of shocks is through variance decompositions. We ask what fraction of the variance of the $k$-step ahead forecast revision $E_{t}\left(Y_{t+k}\right)-E_{t-1}\left(Y_{t+k}\right)$ in, for example, real house prices, is accounted for by monetary policy and capital flows shocks.

Table 4 reports the variance decompositions at different forecast horizons. Shocks which reduce aggregate demand in ROW — 'savings glut' shocks - explain a larger fraction of the variation in real residential investment and real house prices than other types of shocks at all forecast horizons. For example, at a forecast horizon of 20 quarters, negative aggregate demand shocks in ROW explain about $7.5 \%$ of the variation in real residential investment and $10.7 \%$ of the variation in real house prices. We interpret $10.7 \%$ as a sizable fraction, given that house prices should be affected by other shocks that we are not identifying, such as mortgage market innovations.

The variance decompositions confirm the limited role of US monetary policy shocks in explaining the housing boom - these shocks explain less than $3 \%$ of the variation in real residential investment and house prices. Other shocks which generate capital inflows to the US explain a larger fraction of the variation in the housing variables than US monetary policy shocks, but are less important than 'savings glut' shocks'.

Table 4. Variance decompositions

\begin{tabular}{lllllll}
\hline \hline & \multicolumn{3}{l}{ Real residential investment } & \multicolumn{3}{l}{ Real house prices } \\
& 1 Year & 3 Years & 5 Years & 1 Year & 3 Years & 5 Years \\
\hline Monetary expansion US & $2.4 \%$ & $2.3 \%$ & $2.6 \%$ & $4 \%$ & $3.4 \%$ & $2.5 \%$ \\
Negative AD shock ROW & $8.6 \%$ & $8.9 \%$ & $7.5 \%$ & $5.1 \%$ & $9.7 \%$ & $10.7 \%$ \\
Monetary expansion ROW & $4.9 \%$ & $6 \%$ & $6.3 \%$ & $4.8 \%$ & $8.6 \%$ & $10.1 \%$ \\
Positive AD shock US & $4 \%$ & $3.4 \%$ & $3.8 \%$ & $4.3 \%$ & $4.2 \%$ & $4.5 \%$ \\
Risk premium & $6.5 \%$ & $5.4 \%$ & $4.6 \%$ & $3.1 \%$ & $4.5 \%$ & $4 \%$ \\
\hline \hline
\end{tabular}

${ }^{8}$ All shocks have quite persistent effects. This is consistent with the findings in Uhlig (2005), where monetary shocks explain a significant fraction of the variation in the variables in the model even five years after the shock. 


\subsection{Robustness}

As discussed in Section 3, sign restrictions allow identification of the structural shocks $v$ from the reduced form errors $u_{t}=B v_{t}$. Because the structural shocks satisfy the condition $E\left(v v^{\prime}\right)=I$, the matrix $B$ needs to satisfy the restriction:

$$
\Sigma=E\left(u_{t} u_{t}^{\prime}\right)=E\left(B v_{t} v_{t}^{\prime} B^{\prime}\right)=B B^{\prime}
$$

This leaves many degrees of freedom in specifying $B$. The sign restrictions methodology consists of choosing different matrices $B$ which satisfy this condition. For each choice of $B$, the implied impulse response functions are generated and the impulse responses which satisfy the sign restrictions are kept.

One problem with this approach, as noted in Fry and Pagan (2010), is that each choice of $B$ produces a new model, constituting a new set of structural equations and shocks. Consequently, the sign restrictions approach does not identify a unique model. To summarize the information from multiple models, we present the median and the 16th and 84th percentiles of the impulse responses. We order the impulse responses in ascending order for each variable and each shock and compute these percentiles. The problem is that the sign restrictions procedure averages impulse responses over several models. The model that produces the median impulse responses for, say, house prices in the 'savings glut' shock my not be the same as the model that produces the median impulse responses for house prices in the US monetary policy shock. This comment also applies to other percentiles.

Fry and Pagan (2005) suggest an approach for dealing with this problem. It consists of selecting a single model whose impulse responses are as close to the median responses as possible. This is called the Median Target (MT) method. Figure 6 shows the median and the MT impulse responses for the housing variables. There is not much difference between the median and the MT impulse responses, except for the effect of ROW monetary policy shocks and US aggregate demand shocks on residential investment. Other studies that compare median and MT impulse responses, for example Fry and Pagan (2010) and Canova and Paustian (2010), also do not find large differences between them. It is reassuring that our results remain valid when we impose the restriction that the impulse responses come from the same model. 
Figure 6. Empirical impulse responses: median, MT and 16th and 84th percentiles US monetary policy expansion
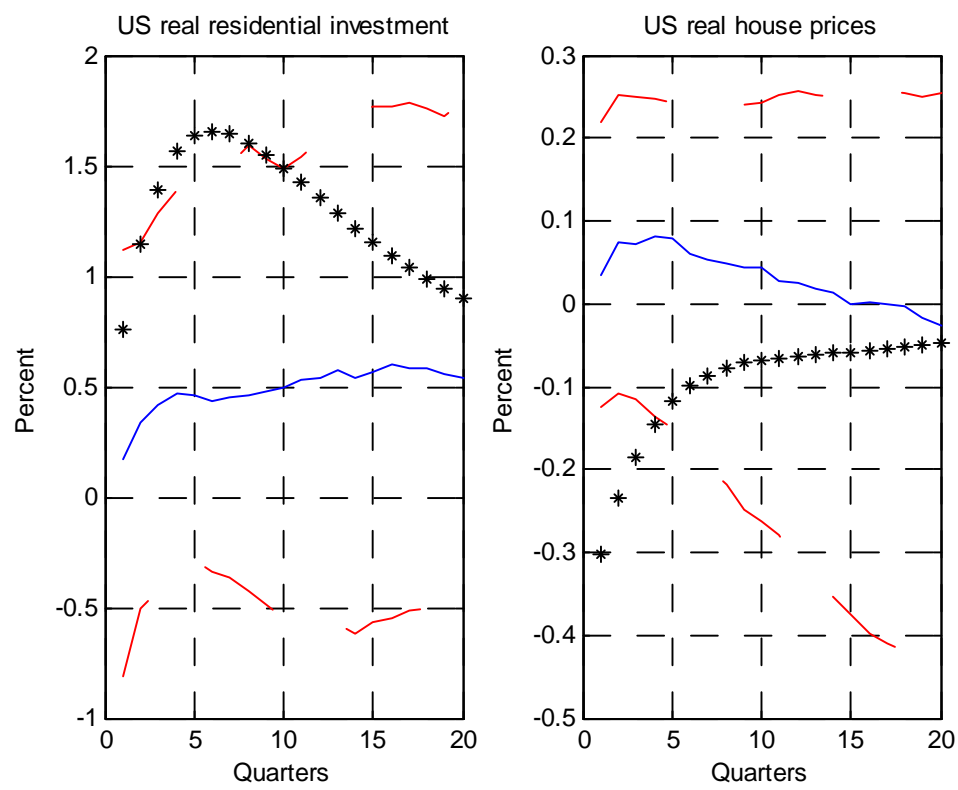

Reduction in aggregate demand in ROW
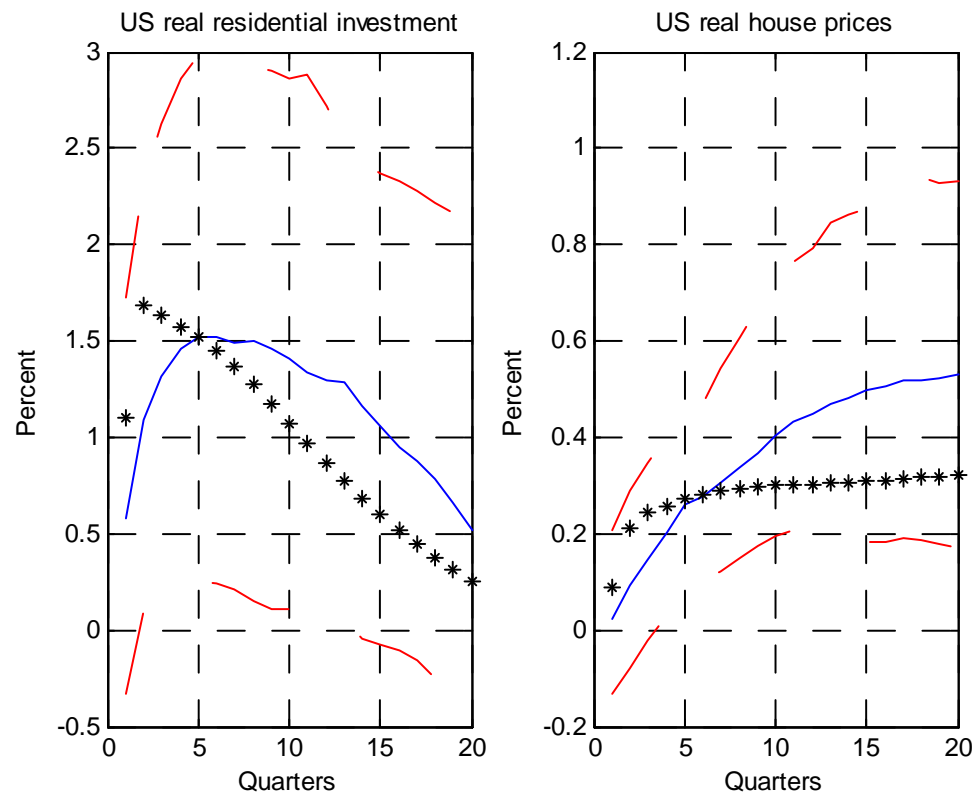
ROW monetary policy expansion
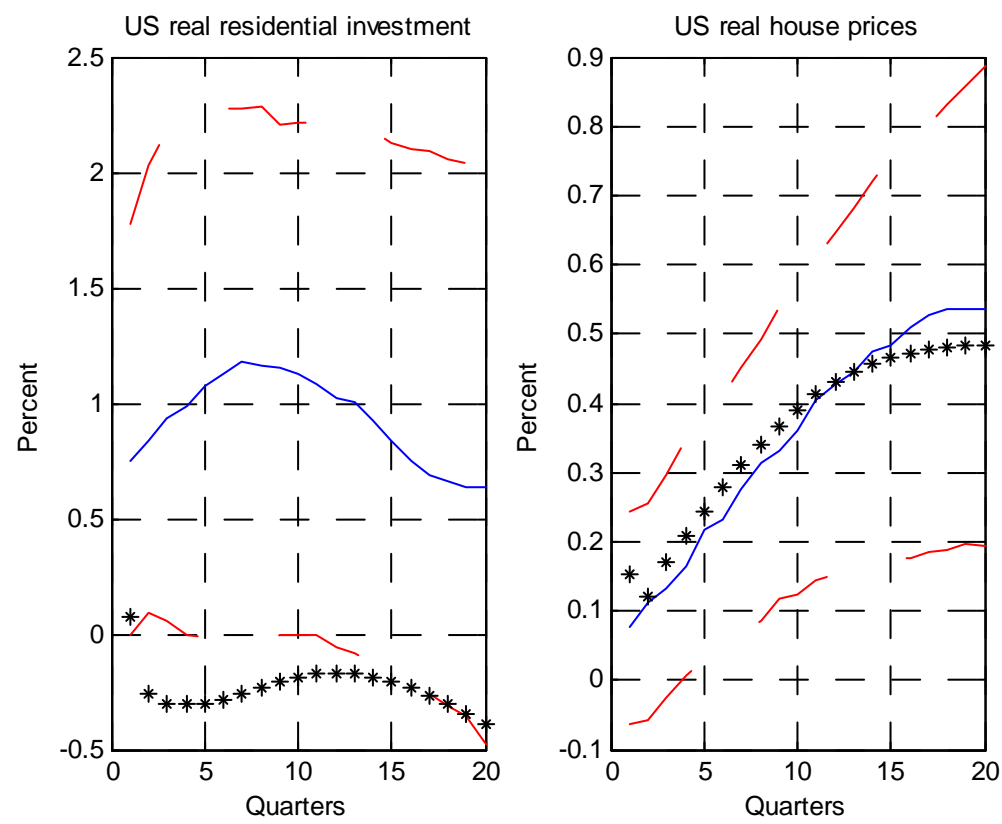

Increase in aggregate demand in the US
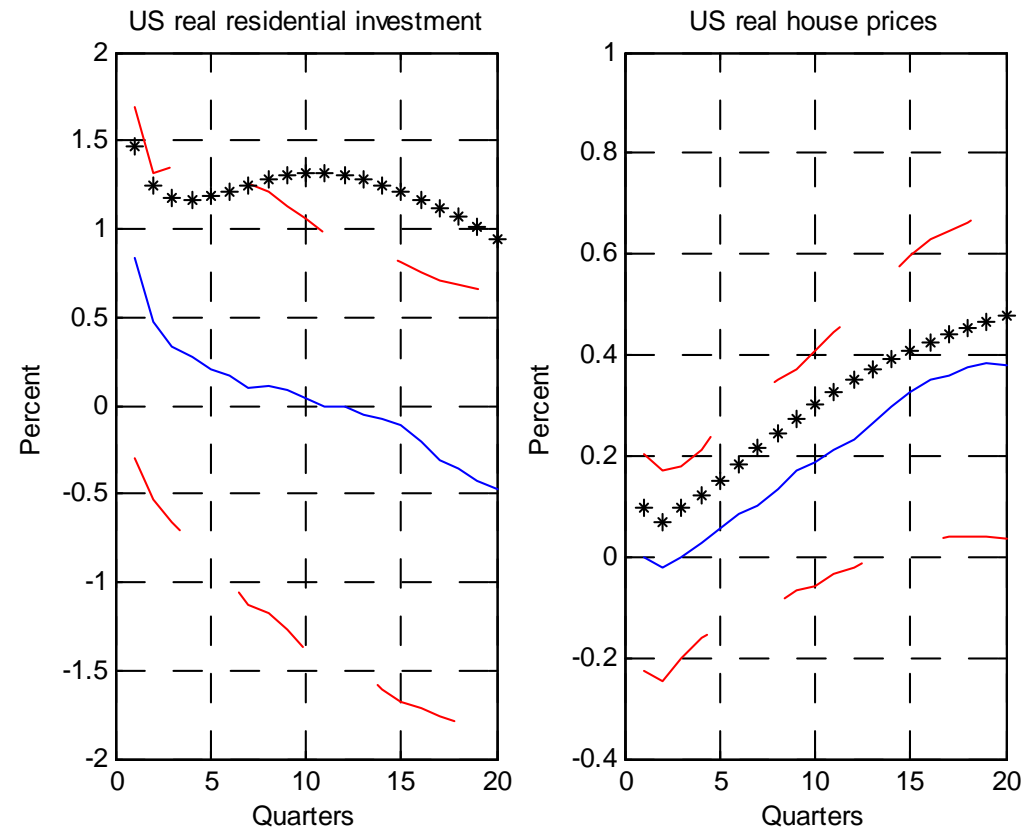
Risk premium shock
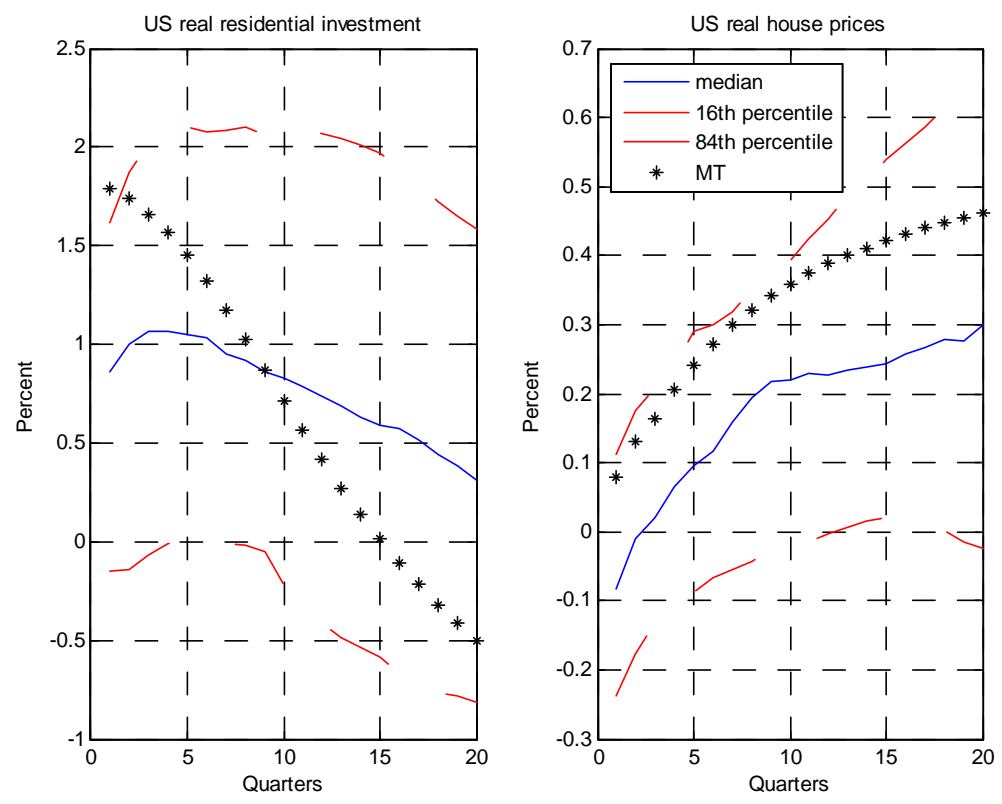

\section{Conclusions}

Prior to the crisis, academics and commentators worried about the sustainability of the US current account deficit and discussed the magnitude of the dollar depreciation that would be required to balance the current account. Here we look at imbalances from a different perspective, focusing on their role in driving down long-term real interest rates and encouraging a house price boom.

Our results suggest that 'savings glut' shocks played a bigger role in driving up house prices than the Federal Reserve's loose monetary policy. While monetary policy shocks had no significant effect on US real residential investment and real house prices, 'savings glut' shocks had a positive and persistent effect on both housing variables. Results from variance decompositions suggest that, at a forecast horizon of 20 quarters, 'savings glut' shocks explain $7.5 \%$ of the variation in real residential investment and $10.7 \%$ of the variation in real house prices. By contrast, monetary policy shocks explain less than $3 \%$ of the variation in both housing variables. Other shocks which generate capital inflows to the US explain a larger fraction of the variation in the housing variables than US monetary policy shocks, but are less important than 'savings glut' shocks. These results highlight the importance of developing policies to prevent the build up of large current account imbalances. 


\section{References}

[1] Banbura, M, Giannone, D, and Reichlin, L (2007), 'Bayesian VARs with Large Panels', CEPR Discussion Papers no. 6326.

[2] Barnett, A and Straub, R (2008), 'What Drives US Current Account Fluctuations?', ECB Working Paper no. 959, November 2008.

[3] Bems, R, Dedola, L and Smets, F (2007), 'US Imbalances: the Role of Technology and Policy', Journal of International Money and Finance, Vol. 26, pages 523-45.

[4] Bernanke, B (2010), 'Monetary Policy and the Housing Bubble', Speech at the Annual Meeting of the American Economic Association, Atlanta, Georgia, 3 January.

[5] Bernanke, B (2005), 'The Global Savings Glut and the U.S. Current Account Deficit', Remarks at the Sandridge Lecture, Virginia Association of Economics, Richmond, Virginia, 10 March .

[6] Betts, C and Devereux, M B (2001), 'The International Effects of Monetary and Fiscal Policy in a Two-Country Model', in Calvo, G A, Dornbusch, R and Obstfeld, M (eds), Money, Capital Mobility, and Trade: Essays in Honor of Robert Mundell, MIT Press.

[7] Bracke, T and Fidora, M (2008), 'Global Liquidity Glut or Global Savings Glut? A Structural VAR Approach', ECB Working Paper no. 911, June 2008.

[8] Caballero, R, Farhi, E and Gourinchas, P-O (2008), 'An Equilibrium Model of 'Global Imbalances' and Low Interest Rates', American Economic Review, Vol. 98(1), pages 358-93.

[9] Caballero, R and Krishnamurthy, A (2009), 'Global Imbalances and Financial Fragility', NBER Working Paper 14688, January 2009.

[10] Canova, F and de Nicoló, G (2002), 'Monetary Disturbances Matter for Business Fluctuations in the G7', Journal of Monetary Economics, Vol. 49(6), pages 1131-59.

[11] Canova, F and Paustian, M (2010), 'Measurement with Some Theory: Using Sign Restrictions to Evaluate Business Cycle Models', Economics Working Papers, Department of Economics and Business, Universitat Pompeu Fabra.

[12] Christiano, L, Eichenbaum, M and Evans, C (1999), 'Monetary Policy Shocks: What Have We Learned and to What End?', Handbook of Monetary Economics.

[13] Corsetti, G, Dedola, L and Leduc, S (2009), 'The International Dimension of Productivity and Demand Shocks in the U.S. Economy', Federal Reserve Bank of San Francisco Working Paper Series 2009-09. 
[14] Dees, S, di Mauro, F, Pesaran, H and Smith, L V (2007), 'Exploring the International Linkages of the Euro Area: a Global VAR Analysis', Journal of Applied Econometrics, Vol. $22(1)$, pages 1-38.

[15] Del Negro, M and Otrok, C (2007), '99 Luftballons: Monetary Policy and the House Price Boom Across U.S. States', Journal of Monetary Economics, Vol. 54, pages 1962-85.

[16] Eichenbaum, M and Evans, C (1995), 'Empirical Evidence on the Effects of Shocks to Monetary Policy on Exchange Rates', The Quarterly Journal of Economics, Vol. 110(4), pages 975-1009.

[17] Farrant, K and Peersman, G (2006), 'Is the Exchange Rate a Shock Absorber or a Source of Shocks? New Empirical Evidence', Journal of Money, Credit and Banking, Vol. 38(4), pages 939-961.

[18] Faust, J and Rogers, J (2003), 'Monetary Policy's Role in Exchange Rate Behavior', Journal of Monetary Economics, Vol. 50, pages 1403-24.

[19] Ferrero, A, Gertler, M, and Svensson, L (2007), 'Current Account Dynamics and Monetary Policy', in International Dimensions of Monetary Policy, National Bureau of Economic Research, pages 199-244.

[20] Fogli, A and Perri, F (2008), 'Macroeconomic Volatility and External Imbalances', University of Minnesota mimeo.

[21] Fry, R and Pagan, A (2005), 'Some Issues in Using VARs for Macroeconometric Research', CAMA Working Paper Series 19/2005.

[22] Fry, R and Pagan, A (2010), 'Sign Restrictions in Structural Vector Autoregressions: a Critical Review', CAMA Working Paper Series 22/2010, forthcoming in Journal of Economic Literature.

[23] Greenspan, A (2005), Testimony to the Congress, 16 February 2005.

[24] Iacoviello, M (2005), 'House Prices, Borrowing Constraints, and Monetary Policy in the Business Cycle', American Economic Review, Vol. 95, pages 739-64.

[25] Jarociński M and Smets, F (2008), 'House Prices and the Stance of Monetary Policy', ECB Working Paper no 891, April 2008.

[26] King, M (2009), Speech at the CBI dinner, Nottingham, 20 January.

[27] Krishnamurthy, A and Vissing-Jorgensen, A (2007), 'The Demand for Treasury Debt', NBER Working Paper no 12881, January 2007. 
[28] Lane, P R (2001), 'Money Shocks and the Current Account', in Calvo, G A, Dornbusch, $\mathrm{R}$ and Obstfeld, M (eds), Money, Capital Mobility, and Trade: Essays in Honor of Robert Mundell, MIT Press.

[29] Lee, J and Chinn, M D (2006), 'Current Account and Real Exchange Rate Dynamics in the G7 Countries', Journal of International Money and Finance, Vol. 25, pages 257-74.

[30] Litterman, R (1986), 'Forecasting with Bayesian Vector Autoregressions - Five Years of Experience', Journal of Business and Economic Statistics, Vol. 4, pages 25-38.

[31] OECD (2000), 'OECD Economic Outlook', No. 68 Chapter VI.

[32] Pappa, E (2009), 'The Effects of Fiscal Shocks on Employment and the Real Wage', International Economic Review, Vol. 50(1).

[33] Peersman, G and Straub, R (2009), 'Technology Shocks and Robust Sign Restrictions in a Euro Area SVAR', International Economic Review, Vol. 50(3).

[34] Pesaran, H, Schuermann, T and Smith, L V (2008), 'Forecasting Economic and Financial Variables with Global VARs'. CESifo Working Paper Series No. 2263.

[35] Prasad, E (1999), 'International Trade and the Business Cycle', The Economic Journal, Vol. 109 , pages $588-606$.

[36] Taylor, J (2009), 'The Financial Crisis and the Policy Responses: an Empirical Analysis of What Went Wrong', NBER Working Paper 14631, January 2009.

[37] Sá, F and Viani, F (2010), 'Shifts in Portfolio Preferences of International Investors: an Application to Sovereign Wealth Funds', Cambridge Working Papers in Economics 1029.

[38] Uhlig, H (2005), 'What are the Effects of Monetary Policy on Output? Results from an Agnostic Identification Procedure', Journal of Monetary Economics, Vol. 52(2), pages 381-419.

[39] Warnock, F and Warnock, V C (2009), 'International Capital Flows and U.S. Interest Rates', Journal of International Money and Finance, Vol. 28, pages 903-919.

[40] Zettelmeyer, J (2004), 'The Impact of Monetary Policy on the Exchange Rate: Evidence from three Small Open Economies', Journal of Monetary Economics, Vol. 51, pages 635-52. 